\begin{tabular}{|c|c|c|c|}
\hline Article Info & RESEARCH ARTICLE & ARAŞTIRMA MAKALESİ & \\
\hline Title of Article & \multicolumn{2}{|c|}{$\begin{array}{l}\text { Investigation of The Usabılity of Kirklareli } \\
\text { Central Yayla and Vilayet Squares in The } \\
\text { Context of Human-Space Interaction }\end{array}$} & \\
\hline $\begin{array}{l}\text { Corresponding } \\
\text { Author }\end{array}$ & \multicolumn{2}{|c|}{$\begin{array}{l}\text { H. Meltem Gündoğdu } \\
\text { Kırklareli Üniversitesi Mimarlık Fakültesi, Şehir ve Bölge Planlama Ana Bilim Dalı, } \\
\text { Kırklareli, gundogdumeltem@ @otmail.com }\end{array}$} & \\
\hline $\begin{array}{l}\text { Received Date } \\
\text { Accepted Date }\end{array}$ & \multicolumn{2}{|l|}{$\begin{array}{l}22.05 .2020 \\
06.07 .2020\end{array}$} & \\
\hline Author / Authors & $\begin{array}{l}\text { H. Meltem GÜNDOĞDU } \\
\text { M. Beyza UĞUZ }\end{array}$ & $\begin{array}{l}\text { ORCID: 0000-0003-1897-2927 } \\
\text { ORCID: 0000-0002-7746-0705 }\end{array}$ & \\
\hline How to Cite & \multicolumn{2}{|c|}{$\begin{array}{l}\text { GÜNDOĞDU, M., UĞUZ, B., (2020). İnsan-Mekân Etkileşimi Bağlamında Kırklareli } \\
\text { Merkez Yayla ve Vilayet Meydanları Kullanılabilirlik Durumunun Araştırılması, } \\
\text { Kent Akademisi, Volume, 13, Issue 2, Pages, 315-337. }\end{array}$} & $\begin{array}{l}\text { Kent Akademisi } \\
\text { Urban Academy }\end{array}$ \\
\hline
\end{tabular}

\title{
İnsan-Mekân Etkileşimi Bağlamında Kırklareli Merkez Yayla ve Vilayet Meydanları Kullanılabilirlik Durumunun Araştırılması
}

\section{H. Meltem GÜNDOĞDU ${ }^{1}$ M. Beyza UĞUZZ ${ }^{2}$}

\begin{abstract}
:
Squares are important urban spaces in understanding the cultural features and historical background of cities, identifying urban identities, urban open spaces where people establish social and cultural communication networks, relax, shop and engage in various activities. Although there are different purposes and reasons of use in the historical process, the most important reason when these aims are listed as commercial, cultural, social, administrative and recreational is the desire and socialization of people. Therefore, the existence of squares is a necessity for all urban inhabitants. A successful challenge that the inhabitants can use effectively must have accessibility, variety of activities, good image and social environment. However, when we look at the usage of today's squares, it is seen that some squares do not provide these qualities. In the observations made in the Vilayet and Yayla squares, one of the oldest and densest squares of Kirklareli city center with different purposes, various usage problems were found. In this regard, in order to reveal the use cases of both squares, spatial analysis, observation, and counting methods were compared to compare the two squares, and the user awareness was discussed through the results of the questionnaire regarding the usage problems and demands. In this direction, spatial analysis, observation, counting and survey methods were used to compare the two squares and suggestions were made in line with usage problems and demands in order to reveal use cases of both squares. As a result of the research, it is a base that can be used in the planning of Kırklareli Central City squares in planning and urban design works and can be updated and used.
\end{abstract}

\footnotetext{
${ }^{1}$ Department of Urban and Regıonal Plannıng, Kırklareli University, Kırklareli, Turkey, gundogdumeltem@ @otmail.com

${ }^{2}$ beyzaoguz13@gmail.com
} 
ÖZ:

Meydanlar, kentlerin kültürel özelliklerinin ve tarihi geçmişinin anlaşılmasında, kimliklerinin belirlenmesinde önemli kent mekânları, insanların sosyal ve kültürel iletişim ağı kurdukları, dinlendikleri, alışveriş yaptıkları, çeşitli aktivitelerde bulundukları kentsel açık alanlardır. Tarihsel süreç içerisinde farklı amaç ve kullanım nedenleri olsa da, bu amaçlar ticari, kültürel, sosyal, yönetimsel ve rekreasyonel şeklinde sıralandığında en önemli neden insanların bir arada bulunma isteği ve sosyalleşmesidir. Bu nedenle tüm kent yaşayanları için meydanların varlığı bir ihtiyaçtır. Yaşayanların etkin olarak kullanabildikleri başarılı bir meydan erişilebilirlik, aktivite çeşitliliği, iyi bir imaj ve sosyal ortam niteliklerine sahip olmalıdır. Ancak günümüz meydan kullanımlarına bakıldığında, bazı meydanların bu nitelikleri sağlamadığı görülmektedir. Kırklareli kent merkezinin farklı kullanım amaçları bulunan en eski ve en yoğun meydanlarından Vilayet ve Yayla meydanlarında da yapılan gözlemlerde çeşitli kullanım sorunlarına rastlanılmıştır. $\mathrm{Bu}$ doğrultuda çalışmada her iki meydanın kullanım durumlarının ortaya çıkarılması amacıyla mekânsal analiz, gözlem, sayım yöntemleri kullanılarak iki meydanın karşılaştırması yapılmış, kullanım sorunları ve taleplere ilişkin yapılan anket sonuçları üzerinden kullanıcı farkındalığı tartışılmıştır. Araştırma sonuçları itibari ile planlama ve kentsel tasarım çalışmalarında Kırklareli Merkez Kent meydanlarının düzenlenmesinde yararlanılabilecek ve güncellenerek kullanılabilecek bir altlık niteliği taşımaktadır.

KEYWORDS: Public Open Spaces, Square Usability, Yayla- Vilayet Squares, Kırklareli

ANAHTAR KELIMELER: Kamusal Açık Alan, Meydan Kullanılabilirliği, Yayla-Vilayet Meydanları, Kırklareli

\section{GíRiş:}

Kentleri farklı ihtiyaçlar doğrultusunda ortaya çıkan mekânlar bütünü olarak kabul edersek, zaman içerisinde kullanıcı ihtiyaçlarının değişmesi ile farklı mekânların oluştuğu görülmektedir. Meydanlar kent olgusu ve gelişimi ile birlikte değişen kullanım amaçlarına rağmen genel bir tanımlama ile kullanıcıların sosyalleştiği, fikir alışverişi yapabildikleri kentsel mekânlardır. Kentsel açık alanlar içinde, insan ilişkileri ve sosyalleşme açısından en önemli mekânlar meydanlardır. İnsanların toplanıp sosyal ve kültürel iletişim ağı kurdukları, dinlendikleri, alışveriş yaptıkları, çeşitli aktivitelerde bulundukları bu alanlar tüm kent kullanıcıları için önemlidir. Mimarlar ve şehir plancılarının en önemli görevlerinden biri, bireylerin kamusal açık alanlarda bir araya gelebilmeleri için meydan alanları oluş̧urmak ve ihtiyaçlar doğrultusunda bu alanları düzenlemektir [1]. Yapılan çalışmalar ve araştırmalar erişilebilirlik, görsel bütünlüğün sağlandığı iyi bir imaj, her yaştan insan için aktivite çeşitliliği ve sosyalleşme ortamının başarılı ve etkin kullanımlı kamusal açık alanların oluşturulmasında anahtar özellikler olduğunu göstermektedir [16].

Ancak günümüz meydan kullanımlarına bakıldığında, meydan özelliği gösteren birçok alanın bu nitelikleri sağlayamadığı, meydanlarda etkin kullanımın olmadığı görülmektedir. Kırklareli kentindeki Vilayet ve Yayla kent meydanlarında yapılan gözlemlerde iki meydanda da çeşitli kullanım sorunlarına rastlanılmıştır. Araştırma; Kırklareli Merkez ilçesi Yayla ve Vilayet meydanlarında, meydanların kullanım nedenlerini, mevcut kullanılabilirlik durumlarını ve kullanııı ihtiyaçlarını ne ölçüde karşıladıklarını analiz ederek kullanılabilirliğin arttırılmasına ilişkin öneriler getirmeyi amaçlamaktadır. Çalışmaya;

- $\quad$ Meydanlarda Etkin Kullanım Nasıl Olur?

- Meydanların Kullanım Nedenleri Nelerdir?

- Kullanıcı Talep ve İstekleri Nelerdir? Araştırma soruları ile başlanmış, çalışma kapsamında,

-Kırklareli kenti içinde farklı kullanım amaçları ile en yoğun kullanım alanları olan Vilayet ve Yayla meydanlarının kullanılabilirlik durumları,

-Kullanıcı tercih, memnuniyet ve talepleri ortaya çıkarılarak meydan kullanılabilirliğinde kullanıcı farkındalığı tartışılmıştır. 
Her iki meydanda da meydan kullanılabilirliğinin arttırılmasına ilişkin önerilerin getirilmesi ana hedef olarak belirlenmiştir. $\mathrm{Bu}$ kapsamda mekânsal analiz, gözlem ve sayım metotları ile seçilen meydanların bağlantılılıkerişilebilirlik, konfor ve imaj, kullanım ve aktivite olanakları ve sosyalleşme ortam nitelikleri ana kriterler olarak ele alınarak her kriter belirlenen alt başlıklarla değerlendirilmiş, aynı zamanda kullanıcı memnuniyeti, ihtiyaç ve taleplerini ortaya çıkarmak amacıyla kullanıcı anketi hazırlanarak her iki meydanda belirlenen sayılarda anket çalışması yapılmıştır.

\section{2. İNSAN-MEKÂN ETKİLEȘIMİ BAĞLAMINDA MEYDANLAR}

Meydanlar, kentlerin kültürel özelliklerinin ve tarihi geçmişinin anlaşılmasında, kimliklerinin belirlenmesinde, nitelikli ve özgün karakterli kentlerin oluşumunda etkili, sosyal yaşama hizmet eden kamusal açık alanlardır. Meydanı tanımlarken öncelikle kamusal açık alan kavramını ele almak gereklidir. Geçmişten günümüze kadar farklı kültürlerde açık alan kavramı değişik anlam ve boyutlar ifade etmiştir. "İ̀ster binalar arasında bırakılmış boşluklar, mabet veya saray önü toplanma alanları, ister yolların kesişme yeri veya kavşaklar şeklinde ortaya çıkmış olsun kamusal açık alan ve bunları kullanma düşüncesi yerleşmeler tarihi kadar eskidir” [2]. Kamusal açık alan; cinsiyet, ırk, etnik köken, yaş veya sosyo-ekonomik seviyesine bakılmaksızın tüm insanlara açık ve erişilebilir bir alanı veya yeri ifade eder. Bunlar kaldırımlar ve sokaklar, meydanlar ve parklar gibi halka açık ortak kullanım alanlarıdır. Bu alanlar kentin ayrılmaz bir parçasıdır. İnsanlar için kamusal yaşamı, sosyal hayatı ve etkileşimi destekleyen fiziksel ve sosyal boyutları olan bir ortamdır. Kent içinde gerçekleşen etkinlikler, olaylar ve mekânlar, bu alanları sosyo-kültürel bir alan haline getirir [3]. Aynı zamanda yaşayanlar için toplantı yerleri sağlama, yerel gelenekler için alan tanımlama gibi farklı işlevleri yerine getirir [4]. Kamusal açık alanlar, açık havada çeşitli aktivitelere ev sahipliği yapan, yaşayanların kentsel deneyimin tadına varmasını sağlayan, sokak eğlencesinden yeme-içmeye, spor ve oyun alanlarından sivil ya da politik alanlara birçok fonksiyonu barındıran, yürümek ya da dinlenme ihtiyacına cevap veren kentsel mekânlardır [5]. Bu alanlar, mekânla yaşayanlar arasında doğrudan bir ilişki kurduğunda en iyi şekilde çalışırlar [6]. Carmona vd. (2010) yaptıkları çalışmada kamusal açık alanlarda mekan ve yaşayanlar arasındaki ilişkinin kurulmasına, bu alanların kullanımlarına dair belirledikleri ilkelerle değinmektedirler. Kamusal açık alan kullanımı için üç ana tasarım ilkesi bulunmaktadır. Birincisi insanların çok yönlü alanlara bağlanmalarını sağlamak, ikincisi tüm kullanıcı gruplarının hakkını korumak eşit imkân sağlamak, üçüncüsü ise yaşayanlara erişilebilirlik ve hareket özgürlüğü sağlamaktır [3]. Bu özellikler birincil açık alan karakteristikleridir. Tüm bu tanımlamalarda kullanılabilirliği etkin bir kamusal açık alanda herkes için eşitlik, erişilebilirlik ve sosyalleşmenin sağlanabilmesi ön plana çıkmaktadır. Bu mekânlar insanların birbiriyle karşılaştıkları alanlardır. Bu kapsamda psikolojik ihtiyaçların karşılanması, sosyal ilişkilerin sağlanması gibi önemli işlevleri yüklenmektedir. Her yaştan ve her kesimden insanın erişebileceği şekilde düzenlenmesi temel ilkedir.

Shirvani’ye göre kamusal açık alanlar parklar, meydanlar, yeşil alanlar olarak sınıflandırılabilir [7]. Krier'e göre ise kentlerin ilk oluşumlarında etkili olan kamusal açık alanlar, sokak ve meydan olarak iki başlıkta incelenebilir. Meydanlar, kentsel iletişim ve birlikteliğin mekânlarıdır. Sokaklar ise, meydanların oluşumu ve çevresinin şekillenmesi ile gelişir [8]. Tüm sınıflandırmalara göre, kentsel mekânlar arasında en önemli açık alanlar meydan mekânlarıdır. Zucker'e (1959) göre meydan mekânları mimarisi güçlü toplumsal işlevleri olan şehir dokusuna entegre olmuş alanlardır [9],[10]. Lynch'e göre meydanlar yüksek katlı binaların ve birçok caddenin birleştiği yoğun aktivite merkezleri ve insanların sosyal iletişim kurduğu odak noktalarıdır [11]. Meydan mekânını oluşturan öğeler, öğeler arası ilişkiler ve kullanım nedenleri tarih boyunca değişim gösterse de, oluşumlarındaki en önemli amaç kullanıcılar arası ilişki ve bilgi alışverişinin sağlanmasıdır. Bu kapsamda sosyalleşme ortamının yaratılması esastır. Aynı zamanda çekici unsurların ve aktivite çeşitliliğinin ön plana çıkartılması, her yaştan kullanıcının etkin faydalanmasını sağlayacaktır.

Binin üzerinde kamusal mekân proje tecrübesi bulunan A.B.D. Merkezli "Kamusal Mekânlar için Proje Şirketi PPS"’e göre tüm kamusal açık alanlarda kullanılabilirliğin sağlanmasında erişilebilirlik, konfor ve imaj, aktivite çeşitliliği ve sosyalleşme ortamı yaratılması anahtar özelliklerdir. Bu özellikler göz önünde bulundurularak gerçekleştirilen düzenlemelerle bir sokak, bir meydan, su kenarı, oyun alanı, pazar veya park alanı kullanımı etkin, başarılı bir kamusal alan sunacaktır [17] (Tablo 1). 
Tablo 1. Başarılı Kamusal Alan Anahtar Nitelikleri [17]

\begin{tabular}{|c|c|c|}
\hline Anahtar Nitelikler & Kapsadığı Alt Başlıklar & Ölçme Değerlendirme Kriterleri \\
\hline Bağlantısallık-Erişebilirlik & $\begin{array}{c}\text { Süreklilik } \\
\text { Yakınlık } \\
\text { Bağlantılılık } \\
\text { Okunabilirlik } \\
\text { Yürünebilirlik } \\
\text { Uygunluk }\end{array}$ & $\begin{array}{c}\text { Trafik Bilgisi } \\
\text { Ulaştırma Türleri } \\
\text { Transit Kullanım } \\
\text { Yaya Aktivitesi } \\
\text { Park Alanı Durumu }\end{array}$ \\
\hline Sosyalleşme & $\begin{array}{c}\text { Çeşitlilik } \\
\text { Komşuluk } \\
\text { Arkadaşlık } \\
\text { İlişkisellik } \\
\text { Karşılama } \\
\text { Yönetim }\end{array}$ & $\begin{array}{c}\text { Tercih Eden Kullanıcı } \\
\text { Sosyal Ağ } \\
\text { Gönüllülük } \\
\text { Gece Kullanımı } \\
\text { Sokak Hayatı }\end{array}$ \\
\hline Kullanım Ve Aktivite Çeşitliliği & $\begin{array}{c}\text { Eğlence } \\
\text { Verimlilik } \\
\text { Aktiflik } \\
\text { Yerellik } \\
\text { Kutlama } \\
\text { Sürdürülebilirlik }\end{array}$ & $\begin{array}{l}\text { Yerel İş Sahipliği } \\
\text { Alan Kullanımı } \\
\text { Mülkiyet Değerleri } \\
\text { Kira Düzeyi } \\
\text { Kiralama Değerleri }\end{array}$ \\
\hline Konfor Ve İmaj & $\begin{array}{c}\text { Güvenli } \\
\text { Temiz } \\
\text { Yeşil } \\
\text { Çekici } \\
\text { Tarihi } \\
\text { Oturulabilir }- \text { Yürünebilir }\end{array}$ & $\begin{array}{l}\text { Suç İstatistiği } \\
\text { Temizlik Durumu } \\
\text { Yapı Durumu } \\
\text { Çevresel Bilgi }\end{array}$ \\
\hline
\end{tabular}

Tablo 1'de başarılı bir kamusal alan anahtar nitelikleri ve bu niteliklerin değerlendirilebilmesinde kullanılabilecek alt başlıklar görülmektedir. Bağlantısallık-Erişilebilirlik; kamu alanlarına yakınlığın ve ulaşılabilirliğin sağlanması, kent içi bağlantı ve erişimin yeterli ve sürekli olması, alana yürünebilir olması değerlendirme kriterleri ile ele alınmaktadır. Erişimde ulaştırma çeşitleri, transit kullanım, yaya kullanım kolaylığı, otopark alanı yeterliliği, trafik yoğunluğu bu alt başlıkların değerlendirilmesindeki ölçme kriterleri olarak belirlenmiştir. Sosyalleşme Ortamı, sosyal ortam çeşitliliğinin sağlanması, komşuluk arkadaşlık ilişkileri ve etkileşim ortamının bulunması, alanın yönetimi ve ilk karşılama başlıkları ile ele alınmış, mekânı tercih eden kullanııı tipi, sosyal ağ ve ilişkiler düzeyi, gönüllülük, gece kullanımı ve sokak hayatı varlığı ölçme kriterleri olarak belirlenmiştir. Kullanım ve Aktivite çeşitliliğinin değerlendirilmesinde, verimli, faydalı, aktif ve sürdürülebilir kullanım özelliklerinde olma, yerel kullanım ve yerel iş olanaklarının bulunması, eğlence ve kutlama gibi aktiviteler için kullanım alt başlıkları ele alınmış, bu alt başlıkların değerlendirilmesinde, yerel iş sahipliği oranı, fonksiyonel kullanım özellikleri, perakende ticaret yoğunluğu, kiralama ve mülkiyet değerlerinin oranları ölçme kriterleri olarak belirlenmiştir. Konfor ve imaj niteliği mekânın öncelikle güvenli, temiz, yeşil ve çekici özelliklerde olması, tarihi çevrelerle bütünleşme özelliği göstermesi, yeterli oturma ve yürünebilir mekânsal özellikte olması alt başlıklarında ele alınmış, bu alt başlıkların değerlendirilmesinde suçluluk oranlarının tespiti, temizlik durumu, yapı durumu - yapılanma özellikleri ve çevresel kalite değerleri ölçme kriterleri olarak belirlenmiş̧ir. Anahtar nitelikler neleri kapsamalı, nasıl ölçülmeli soruları ile oluşturulan tablo 1'deki kabuller "meydan kullanılabilirliklerinin" değerlendirilmesinde, her yer'in kendi karakteristik özellikleri göz önünde bulundurularak yapılacak mekânsal analiz ve gözlemlere izin veren altlık niteliği taşımaktadır.

Kamusal açık alanların düzenlenmesinde mevcut mekânsal özelliklerin bilinmesi ile birlikte kullanıcıların mekânı kullanım özellikleri, talep ve ihtiyaçlarının bilinmesi tasarımsal yaklaşımlar için tamamlayıcı niteliktedir. Kamusal açık alan kullanımlarında insan-mekân etkileşimi ile etkin planlama bu açıdan birçok disiplinin de konusudur. Ulaşım planlama için, yaya-taşıt ilişkilerinin dengeli çözümü ve yoğun trafik sisteminin nefes alınacak yerlerle desteklenmesi gereklidir. Toplumsal planlama için, toplum bilincinin nesiller arasındaki ilişkilerini, kültürel bütünleşme ve gelişmelerin sağlanmasındaki önemi, ekonomik planlama için tüketici gruplarının rahat konforlu bir ortamda alışveriş yapmasına olanak sağlaması gereklidir. Toplum sağlığı açısından hem beden hem ruh sağlı̆̆ı için kamusal açık 
alanların güvenli ve olanaklı şekilde düzenlenmesi, ilgili tüm disiplinlerin uzmanlığı ile birlikte her başlığın mekândaki mevcut durumuna ilişkin analizi de gerekli kılar [1].

Meydanlarda başarılı ve etkin kullanımın sağlanabilmesi de insan-mekân arasındaki ilişkinin kurulabilmesi ile doğru orantılıdır. Mekânsal ve gözlemsel analiz verileri ile belirlenebilen meydan kullanılabilirlik durumları, kent meydanlarını kullanan yaşayanların, meydan özelliklerinin ve eksikliklerinin farkında olması, önem vermesi ve bu alanları yaşadıkları yerin ayrılmaz bir parçası olarak görerek ihtiyaç ve gereksinimlerini belirlemeleri yapılan analizleri destekleyecektir. Aynı zamanda meydanların kullanılabilirlik durumu ile birlikte kullanıcı özelliklerinin bilinmesi, yerel yönetimlerle yaşayanlar arasında arz-talep dengesinin kurulmasını, meydan ve çevresi düzenleme çalışmalarında etkin, yönlendirici ve doğru veriye ulaşılmasını sağlayacaktır (Şekil 1).

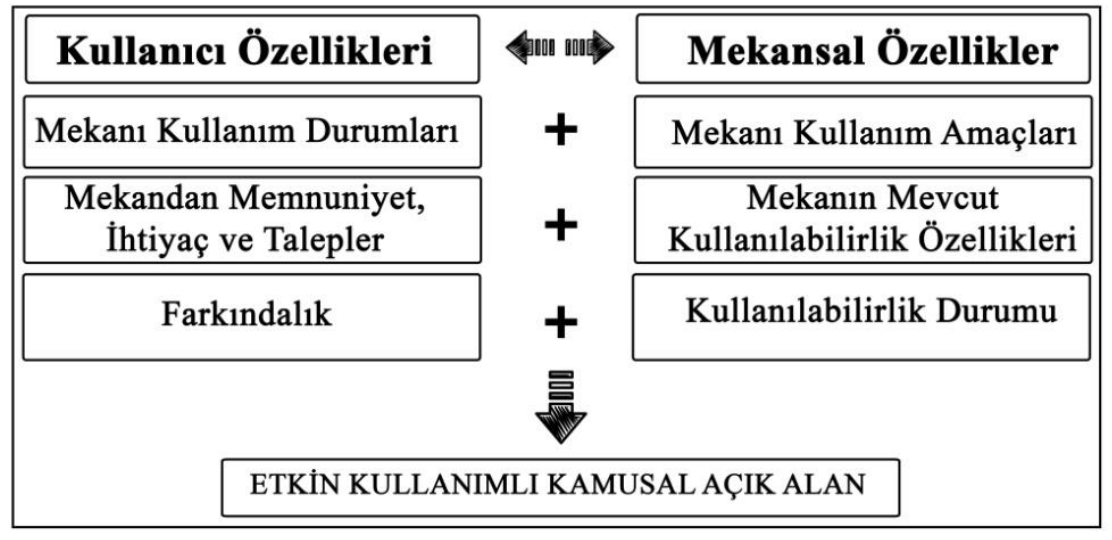

Şekil 1. Kamusal Açık Alanlarda İnsan - Mekân İlişkisi

\section{ÇALIŞMANIN YÖNTEMI}

Çalışma kapsamında incelenen Kırklareli kentinin en yoğun kullanıma sahip olan Yayla ve Vilayet meydanlarının kullanılabilirlik değerlendirilmesi ve meydanlarda kullanımın nasıl olduğunu anlayabilmek için öncelikle başarılı açık alan kullanımı anahtar kriterleri üzerinden mekânsal analiz, gözlem ve sayım yöntemleri ile bir değerlendirme sistemi oluşturulmuş ve iki meydanın kullanım özellikleri alt başlıklar üzerinden değerlendirilmiştir. Kullanıcı özelliklerinin belirlenebilmesi için kullanıcıların meydan kullanım nedenleri, meydanı kullanma sıklıkları, memnuniyetleri, kullanıcı ihtiyaç ve taleplerini değerlendiren anket soruları hazırlanmış ve her iki meydan da belirlenen sayıda anket çalışması yapılmıştır.

\subsection{Mekânsal Analiz - Gözlem - Sayım Çalışmaları}

Her iki meydanın meydan kullanımında anahtar nitelik olarak ele aldığımız ana kriterler ve bu kriterlerin ölçümlenmesinde kullanılacak alt başlıklara ilişkin yöntemleri ile birlikte bir değerlendirme tablosu oluşturulmuştur (Tablo 2). Kamusal bir alanın erişilebilirliği, hem görsel hem de fiziksel çevresiyle olan bağlantılarıyla değerlendirilmelidir. Bir kamusal alana kolay erişim ve ulaşım sağlanması ve herkesin erişebilirliğinin önemsenmesi en önemli anahtar unsurdur. İnsanlar bu yere kolayca yürüyebilir mi? Mekândaki yollar insanları gerçekten gitmek istedikleri yere götürüyor mu? İnsanların mekâna ulaşabilmeleri için çeşitli ulaşım seçenekleri (otobüs, tren, araba, bisiklet vb.) sunuluyor mu? Engelli ulaşımı kolayca sağlanabiliyor mu? Araçlar alanın yaya kullanımına imkân veriyor mu? şeklindeki sorular erişim ve bağlantılılığın değerlendirme kriterlerini oluşturmaktadır. Bu çalışmada, erişilebilirlik-bağlantısallık anahtar niteliği; bağlantı olanakları ve erişilebilirlik şeklinde ele alınmış, erişilebilirlik başlığı altında ulaşım alternatifleri değerlendirilmiş ve engellilere düzenleme varlığına bakılmıştır. Bağlantı olanakları başlığı altında anayol bağlantılılı̆g 1 ve tali yol bağlantılılığı değerlendirilmiştir. Bir mekânın sosyal bir ortam yakalaması zor ancak çok önemlidir. İnsanlar arkadaşlarını gördüklerinde, komşularıyla tanışıp selamlaştıklarında ve yabancılarla etkileşimde bulunduklarında kendilerini rahat hissettiklerinde, topluluklarına ve bu tür sosyal aktiviteleri teşvik eden yere daha güçlü şekilde bağlılık hissetme eğilimindedirler. Burası arkadaşlarınızla tanışmayı tercih edeceğiniz bir yer mi? Burada arkadaşlarla buluşuluyor mu veya onlarla karşılaşıllyor mu? İnsanlar yeri düzenli olarak ve seçerek kullanıyor mu? gibi sorularla sosyalleşme ortamı değerlendirilebilir. Çalışmada, sosyalleşme anahtar niteliği; meydanları tercih eden kullanıcı tipi, gece kullanımı, sokak hayatı canlılığı, sosyal ağlar ve ilişkiler 
alt başlıkları gözlem ve sayım yöntemleri ile değerlendirilmiştir. Bir mekânın rahat ve kendini iyi sunması - iyi imajı başarısının anahtarıdır. Bir kamusal alanı insanların ziyaret etmelerinin nedeni bu alandaki etkinliklerdir. Bir yeri özel veya benzersiz kılan da onlardır. Farklı yaşlardaki insanların alanı kullanması, hem tekil hem de gruplar halinde insanlar tarafından kullanılması, insanların arkadaşlarıyla oturabilecekleri yerler olması, daha fazla sosyalleşme olduğunu gösterir. İnsanlar alanı kullanıyor mu yoksa boş mu? Farklı yaşlardaki insanlar tarafindan kullanılıyor mu? Farklı aktiviteler gerçekleşiyor mu? şeklindeki sorular kullanım ve aktivitelerin değerlendirilmesinde esastır. Çalışmada, kullanım ve aktivite olanakları, kamusal alan yeterliliği, günlük ticari alanlara erişebilirlik, donatı alanlarına yakınlık alt başlıkları ile yürüme mesafesi baz alınarak, yerel iş sahipliği, aktivite çeşitliliği alt başlıkları ise var olup olmamalarına göre değerlendirilmiştir. Konfor, güvenlik, temizlik ve oturulacak yerlerin mevcudiyeti hakkındaki algıları içerir. Mekân iyi bir ilk izlenim bırakıyor mu? Oturmak için yeterli ve uygun yer var mı? Alanlar temiz mi ve çöp içeriyor mu? Bölge güvende mi? şeklindeki sorular mekânın konfor ve imajının değerlendirme ölçütlerinin belirlenmesinde önemlidir. Konfor ve imaj anahtar niteliği, açık alanlarda iyi bir imaj oluşturmada önemli olan tarihi bir çevre ye yakınlık kimlikli yapı varlığı ile, güvenlik açısından gece-gündüz kullanımının tespiti, konfor şartlarının belirlenmesinde kötü koku, olumsuz görüntü, gürültülü ortam, iklimsel olumsuzluk ve kirlilik varllğı ile çevresel kaliteyi olumsuz etkileyen faktörler, görüş alanı açıklık-kapalılık hissi, görsel alan bütünlüğünün sağlanmasında yapı bütünlüğü, yapı ve çevresi bütünlüğü alt başlıkları ile değerlendirilmiştir (Tablo 2).

Tablo 2. Meydan Kullanılabilirliğinde Değerlendirme Sistemi

\begin{tabular}{|c|c|c|c|c|}
\hline ANAHTAR NITTELİKLER & \multicolumn{3}{|c|}{ DEĞERLENDİRMEDE ALT BAŞLIKLAR } & $\begin{array}{l}\text { DEĞERLENDİRME } \\
\text { YÖNTEMİ }\end{array}$ \\
\hline \multirow{7}{*}{ ERİŞILLEBILİRLİK/BAĞLANTILILIK } & \multirow{2}{*}{$\begin{array}{l}\text { Bağlantı } \\
\text { Olanakları } \\
\end{array}$} & \multicolumn{2}{|c|}{ Anayol Bağlantılılı̆̆ } & \multirow{7}{*}{ MEKÂNSAL ANALIZ } \\
\hline & & \multicolumn{2}{|c|}{ Tali Yol Bağlantılılığı } & \\
\hline & \multirow{5}{*}{ Erişilebilirlik } & \multirow{4}{*}{ Ulaşım } & Yaya Ulaşımı (Süreklilik) & \\
\hline & & & $\begin{array}{l}\text { Bisiklet Yolu } \\
\text { (Var-Yok) }\end{array}$ & \\
\hline & & & $\begin{array}{c}\text { Araç } \\
\text { (Özel-Toplu Taşıma) }\end{array}$ & \\
\hline & & & $\begin{array}{c}\text { Otopark } \\
\text { (Yeterli-Değil) }\end{array}$ & \\
\hline & & \multicolumn{2}{|c|}{ Engellilere Düzenleme (Var-Yok) } & \\
\hline \multirow{4}{*}{ SOSYALLEŞME } & \multicolumn{3}{|c|}{$\begin{array}{c}\text { Tercih Eden Kullanıcı } \\
\text { (Çocuk, Genç, Yetişkin, Yaşlı) kişi sayısı/kapasite) }\end{array}$} & \multirow{4}{*}{ SAYIM-GÖZLEM } \\
\hline & \multicolumn{3}{|c|}{ Gece Kullanımı $\quad$ (Var-Yok) } & \\
\hline & \multirow{2}{*}{\multicolumn{3}{|c|}{ 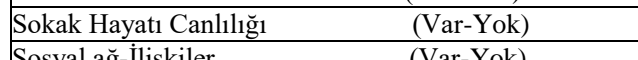 }} & \\
\hline & & \multicolumn{2}{|c|}{\begin{tabular}{|ll} 
Sosyal ağ-İlişkiler & (Var-Yok) \\
\end{tabular}} & \\
\hline \multirow{5}{*}{$\begin{array}{l}\text { KULLANIM VE AKTIVITE } \\
\text { OLANAKLARI }\end{array}$} & \multicolumn{3}{|c|}{ Kamusal Alan Yeterliliği } & \multirow{5}{*}{$\begin{array}{l}\text { MEKÂNSAL ANALIZ - } \\
\text { GÖZLEM }\end{array}$} \\
\hline & \multirow{2}{*}{\multicolumn{3}{|c|}{$\begin{array}{|lc|}\text { Günlük Ticaret Alan. Erişim } & \text { (Yakın-Değil) } \\
\text { Donatı Alanlarına Yakınlık } & \text { (Yakın-Değil) } \\
\begin{array}{l}\text { Yakınlıklar yürüme(5 dakika) } \\
\text { değerlendirilmiştir. }\end{array} & \\
\end{array}$}} & \\
\hline & & & & \\
\hline & \multicolumn{2}{|c|}{ Yerel İş Sahipliği } & (Var-Yok) & \\
\hline & \multicolumn{2}{|c|}{ Aktivite Çeşitliliği } & (Var-Yok) & \\
\hline \multirow{10}{*}{ KONFOR VE İMAJ } & \multirow{2}{*}{\multicolumn{2}{|c|}{\begin{tabular}{|l|} 
Kimlikli Yapı Varlığı \\
Gece-Gündüz Kullanım I \\
\end{tabular}}} & (Var-Yok) & \multirow{10}{*}{$\begin{array}{l}\text { MEKÂNSAL ANALIZ - } \\
\text { GÖZLEM - SAYIM }\end{array}$} \\
\hline & & & (Var-Yok) & \\
\hline & \multirow{5}{*}{$\begin{array}{l}\text { Çevresel } \\
\text { Kaliteyi } \\
\text { Olumsuz } \\
\text { Etkileyen } \\
\text { Faktörler }\end{array}$} & \multicolumn{2}{|c|}{ Kötü Koku } & \\
\hline & & \multicolumn{2}{|c|}{$\begin{array}{l}\begin{array}{l}\text { Olumsuz Görüntü } \\
\text { (Var-Yok) }\end{array} \\
\end{array}$} & \\
\hline & & \multicolumn{2}{|c|}{$\begin{array}{l}\text { Gürültülü Ortam } \\
\text { (Var-Yok) }\end{array}$} & \\
\hline & & \multicolumn{2}{|c|}{$\begin{array}{l}\text { İklimsel Olumsuzluk } \\
\text { (Var-Yok) }\end{array}$} & \\
\hline & & \multicolumn{2}{|c|}{$\begin{array}{l}\text { Kirlilik } \\
\text { (Var-Yok) }\end{array}$} & \\
\hline & Görüş Alanı & \multicolumn{2}{|c|}{ Açıklık Hissi-Kapalılık Hissi } & \\
\hline & \multirow{2}{*}{$\begin{array}{l}\text { Görüs Alan } \\
\text { Bütünlüğü }\end{array}$} & Yap1 & (Var-Yok) & \\
\hline & & Yap1 ve & evresi $\quad$ (Var-Yok) & \\
\hline
\end{tabular}




\subsection{Anket Çalışması}

Kullanıcıların meydan kullanım durumları, kullanım nedenleri, memnuniyetleri ve taleplerinin belirlenebilmesi için anket çalışması yapılmıştır. Her iki meydanda da yapılacak anket sayısının belirlenmesinde örneklem büyüklügü saptanmıştır. Örneklem büyüklüğünün saptanmasında Arkin ve Colton’un \% 5 hata payına göre 100.000'nin üzerindeki nüfus için öngördüğü en az 400 denek sayısı temel alınarak, 1017 kişi kapasiteli Yayla Meydanında 30 kişi ile 3081 kişi kapasiteli Vilayet Meydanında 60 kişi ile anket yapılmıştır [12].

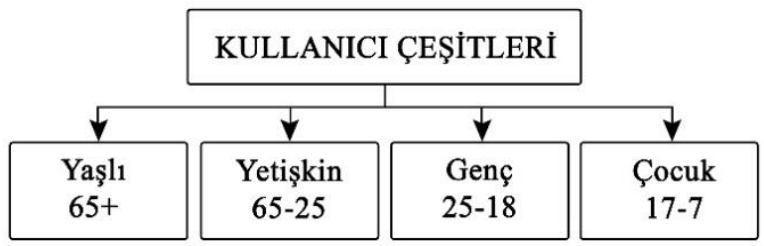

Şekil 2. Kullanıcı Çeşitleri (Yaş’a Göre)

Kullanıcı çeşitleri Türkiye İstatistik Enstitüsü Kurumunun nüfus analizlerinde kullandığı yaş kategorisine göre alınmıştır. 65 yaş üstü Yaşl1, 65-25 yaş arası Yetişkin, 25-18 yaş arası Genç ve 17- 07 yaş arası çocuk olarak değerlendirilmiştir (Şekil 2) (TÜİK, 2018). Yayla Meydanında yapılan gözlemler sonucunda meydan kullanıcı tipinin yetişkin ve yaşlı grubunda yoğun olduğu görülmüştür. Vilayet Meydanında yapılan gözlemler sonucunda ise meydan kullanıcı tipinin genç ve yetişkin grubunda yoğun olduğu görülmüştür. Yapılan anket çalışmasında bu gözlem sonucu değerlendirilerek kullanıcı seçimi yapılmıştır (Şekil 3).

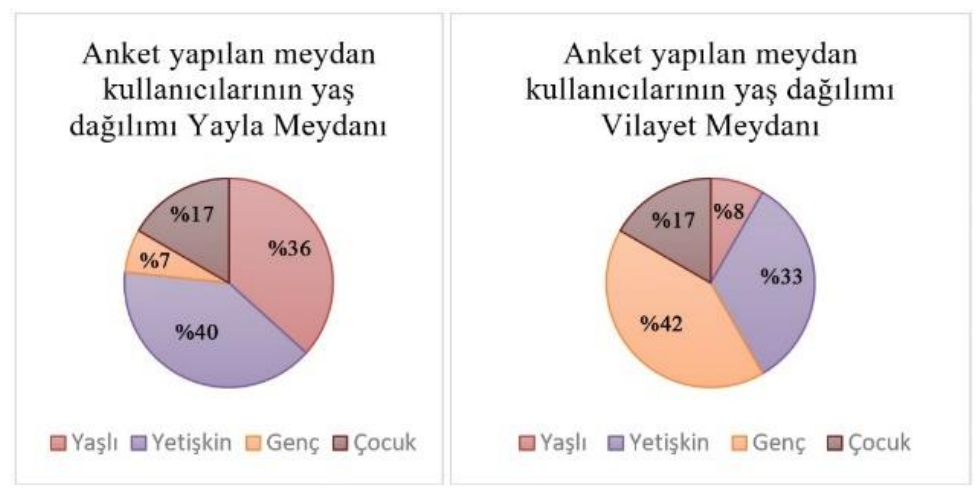

Şekil 3. Anket yapılan Meydan Kullanıcı Yaş Dağılımı

Anket formu kullanıcı özellikleri, Kullanım durumu, Kullanıcı memnuniyeti ve Kullanıcı talepleri başlıkları altında toplanmıştır. Yapılan araştırmada anket sorularından kullanıcıların kullanım durumu ve kullanım nedenleri, kullanıcı memnuniyeti, kullanıcı talepleri başlıkları altında sorulan sorular kullanım durumu ve nedenleri çoktan seçmeli olarak, kullanıcı memnuniyeti beşli skala ile (çok iyi, iyi, orta, kötü, çok kütü) değerlendirilmiştir. 


\section{4. ÇALIŞMA ALANLARININ KONUMU VE ÖZELLIKKLERİ}

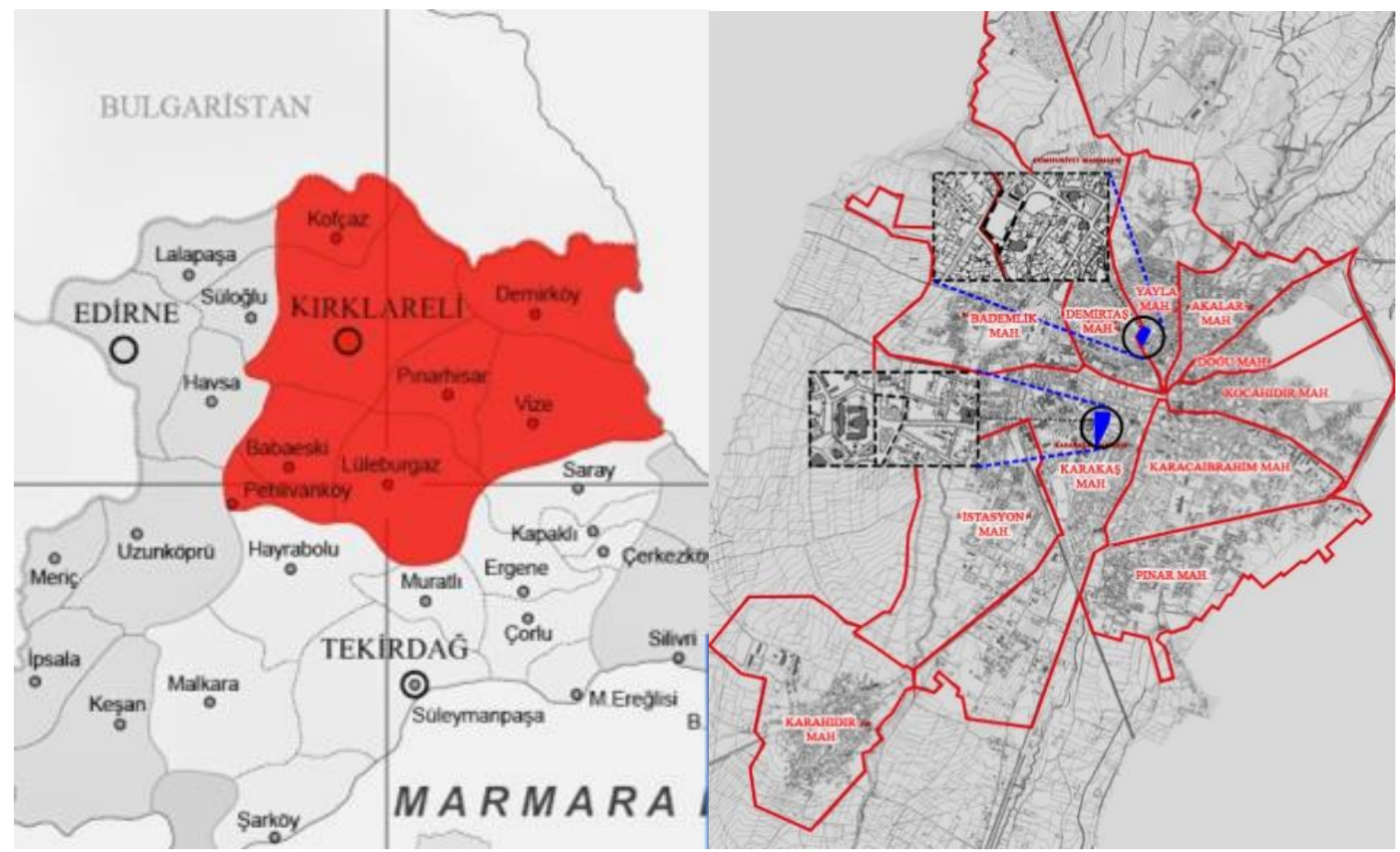

Şekil 4. Kırklareli İli Konumu ve Kırklareli Merkez Mahalle Sınırları ve Yayla - Vilayet Meydan Konumları

Kırklareli ili Marmara'dan Avrupa'ya geçiş alanında ve Bulgaristan ile komşu bir sınır ilidir. Kuzeyinde Bulgaristan, doğusunda Karadeniz, güneydoğusunda İstanbul, güneyinde Tekirdağ, batısında ise Edirne ile sınırlıdır. Merkez, Demirköy, Kofçaz, Babaeski, Pehlivanköy, Babaeski, Lüleburgaz ve Pınarhisar olmak üzere sekiz ilçeye sahiptir. Kent, merkez ilçeye bağlı Akalar, Bademlik, Cumhuriyet, Demirtaş, Doğu, İstasyon, Karacaibrahim, Karahıdır, Karakaş, Kocahıdır, Pınar ve Yayla mahalleleri olmak üzere 12 mahalleden oluşmaktadır (Şekil 4). En eski yerleşim alanları Kırklareli merkez Yayla ve Karakaş mahalleleri olup, Bizans döneminden itibaren Kırklareli merkezi Yayla bölgesinde Rumlar, Bulgarlar, Hızırbey Camii hamam çevresinde ve Kırklar tepesi yöresinde Türkler, Karakaş mahallesinde ise çoğunlukla Yahudiler yaşamıştır [13]. Kırklareli ilk olarak 1363 yılında Osmanlıların eline geçmiş, 1. Dünya Savaşı sıralarında Bulgar ve Yunanlılar tarafından işgal edilmiş, 1922'de işgalden kurtarılarak 1924 yılında "Kırklareli" ismini almıştır. Yayla ve Vilayet meydanları en eski yerleşim alanlarında bulunması, kent için önemli merkezler konumunda olmaları, yoğun kullanımları, yerel ve perakende ticari alanlarının, toplanma, dinlenme, aktivite alanlarının en çok bu meydanlarda bulunması, yaşayanların ve kullanıcıların farklı özelliklerde olmaları ve gözlemsel analizlere göre bazı kullanım sorunları olması nedenleri ile seçilmiştir.

\subsection{Kırklareli Kenti Yayla Meydanı Tarihi Ve Özellikleri}

Yayla Mahallesi Kentin eski yerleşiminin bulunduğu "Kepek Yayla" olarak anılan en önemli geleneksel mahallesidir. Tarihte, Rumlar yoğun olmakla beraber Türkler ve Bulgarların birlikte yaşadığı bir mahalledir. Günümüzde Romen halkının yoğun olarak ikamet ettiği mahallenin önemli bir kısmı kentsel sit alanı içerisinde kalmaktadır. Yayla Meydanı kentin en eski meydan özelliğini taşımaktadır. Merkezinde daha önceleri halkın buluşma alanı olan bir park 
bulunmaktadır. Bu park meydan özelliği taşımaktadır. Yayla Meydanının etrafı özgün tarihi yapılarla çevrilidir. Bu meydan günümüzde tarihi ve turistik açıdan uğrak bir merkezdir (Şekil 5-6).

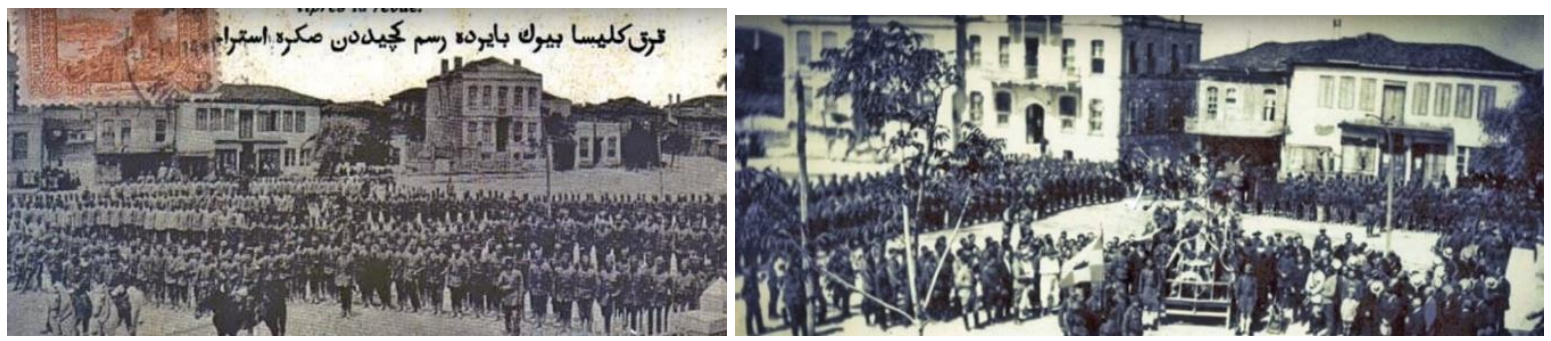

Şekil 5. Yayla Meydanı 1900'lü yıllar (Kırklareli Belediye Arşivi) [18],[19]
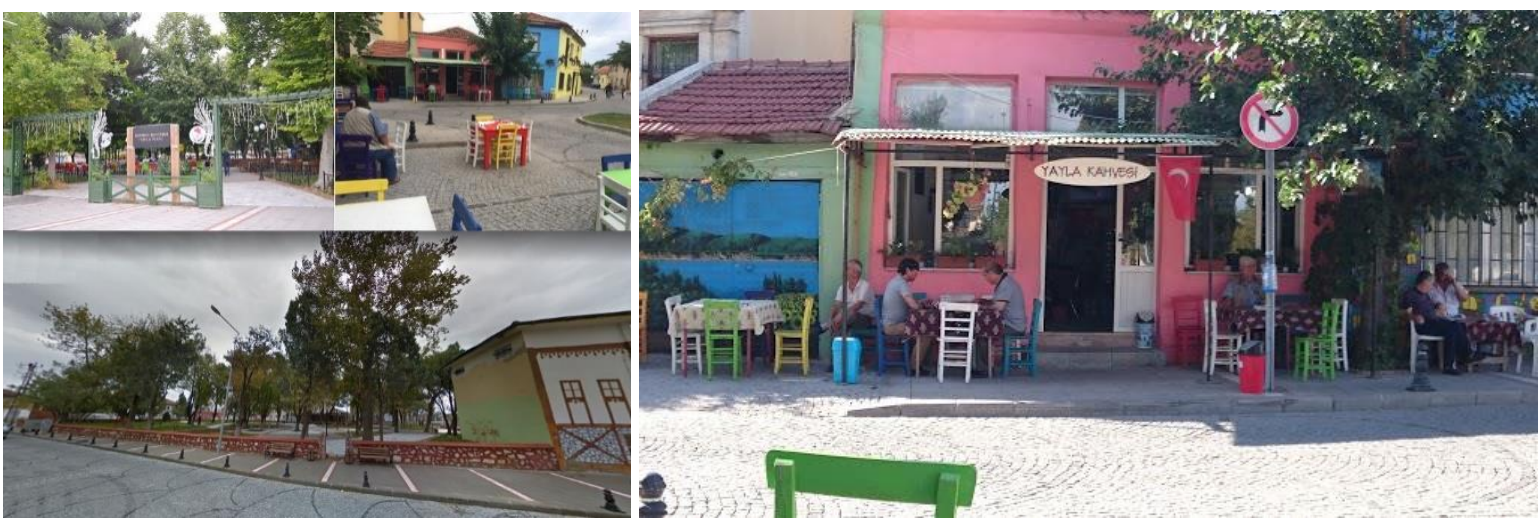

Şekil 6. Yayla Meydanı Günümüz (2018)

Vilayet Meydanı Karakaş Mahallesinde yer almaktadır. Karakaş mahallesi yakın geçmişe kadar Musevi kökenli halkın yoğun olarak ikamet ettiği bir mahalledir. Şehrin omurgasını oluşturan Cumhuriyet Caddesi ve Karaumur Caddesi Karakaş mahalle sınırları içerisindedir. Vilayet Meydanı da bu iki ana aks arasında cumhuriyet caddesi boyunca uzanmaktadır. Vilayet Binası da bu cadde üzerinde yer almaktadır. Meydan kamusal yapılar, ticari yapılar ve tamamı yayaya açık kent kullanıcılarının en çok kullandığı dinlenme, eğlenme, yeme-içme alanı olan İstasyon caddesi ile çevrilidir. Meydanda kavşak niteliğinde bir park ve önemli bir nirengi haline gelmiş [14] uçak maketinin bulunduğu alan ve Atatürk anıtı etrafinda düzenlenmiş bir yeşil alan bulunmaktadır. Bu iki alan yollarla bölünmüş olup meydan bütünlüğü bulunmamaktadır (Şekil 7-8).
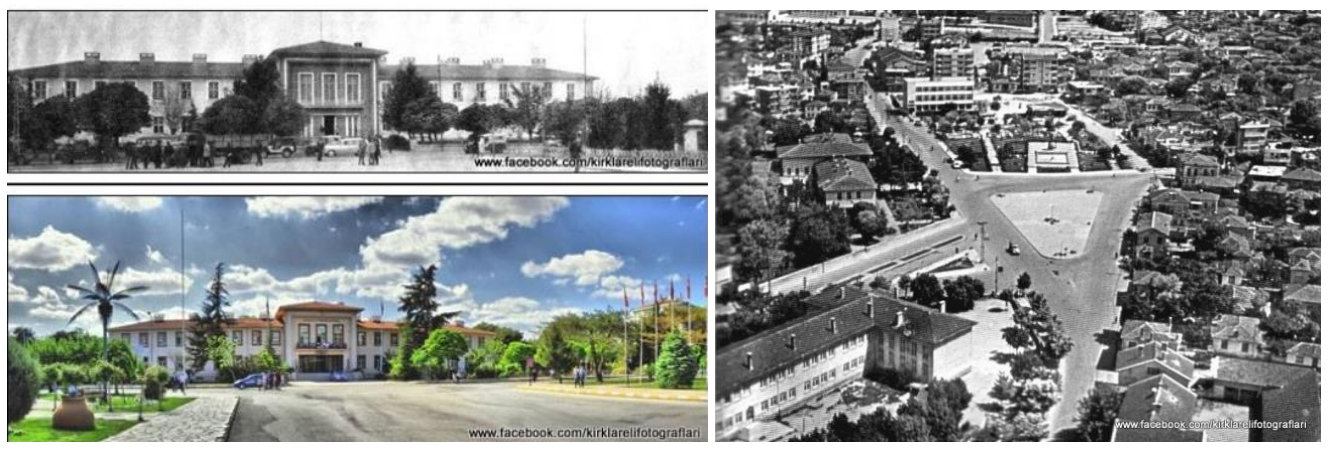

Şekil 7. Vilayet Meydanı Tarihi Ve Günümüz Fotoğrafı (Kırklareli Belediye Arşivi), [18],[19]

İnsan-Mekân Etkileşimi Bağlamında Kırklareli Merkez Yayla ve Vilayet Meydanları Kullanılabilirlik Durumunun Araştırılması

Journal of Urban Academy | Volume: 13 Issue: 2 Yaz 2020 | ISSN: 2146-9229

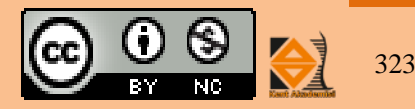




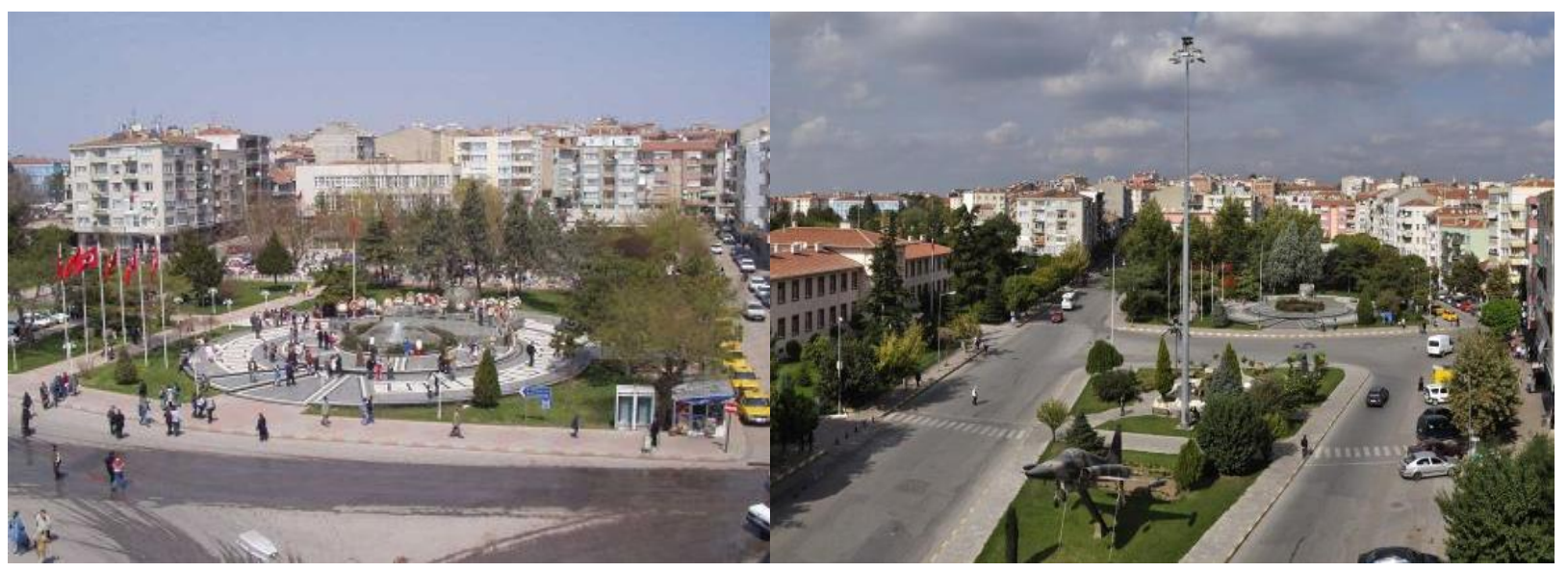

Şekil 8. Vilayet Meydanı Günümüz (2018) [18],[19].

Şekil 9'de Yayla ve Vilayet meydanları yol bağlantıları, aktivite alanları, ticari yapılanma ve kamusal hizmet alanlarına yakınlık görülmektedir. Yayla Meydanı trafikten kısmen arındırılmış, park alanı ve çevresinde gelişen, kentin merkezine biraz daha uzak, tarihi sit alanı içinde yer alan dinlenme ve gezinti alanları yoğun olan, kent müzelerinin yer aldığı kültürel merkez konumunda bir meydan olma özelliği taşımaktadır. Vilayet Meydanı ise kentin merkezinde konumlanması, araç ve yaya trafiğinin, ticari alanların, yeme - içme yerleri ve donatı alanlarının yoğun olmasından dolayı Kırklareli merkez ilçesinin en kalabalık meydanı olma özelliği taşımaktadır. Vilayet Meydanını hem geçiş hem toplanma özelliği gösterdiğinden öncelikle kavşak niteliği ile trafik, ardından alışveriş ve sosyalleşme meydanı, Yayla Meydanını ise öncelikli olarak dinlenme ve gezinti meydanı olarak kabul etmek mümkündür (Şekil 9).

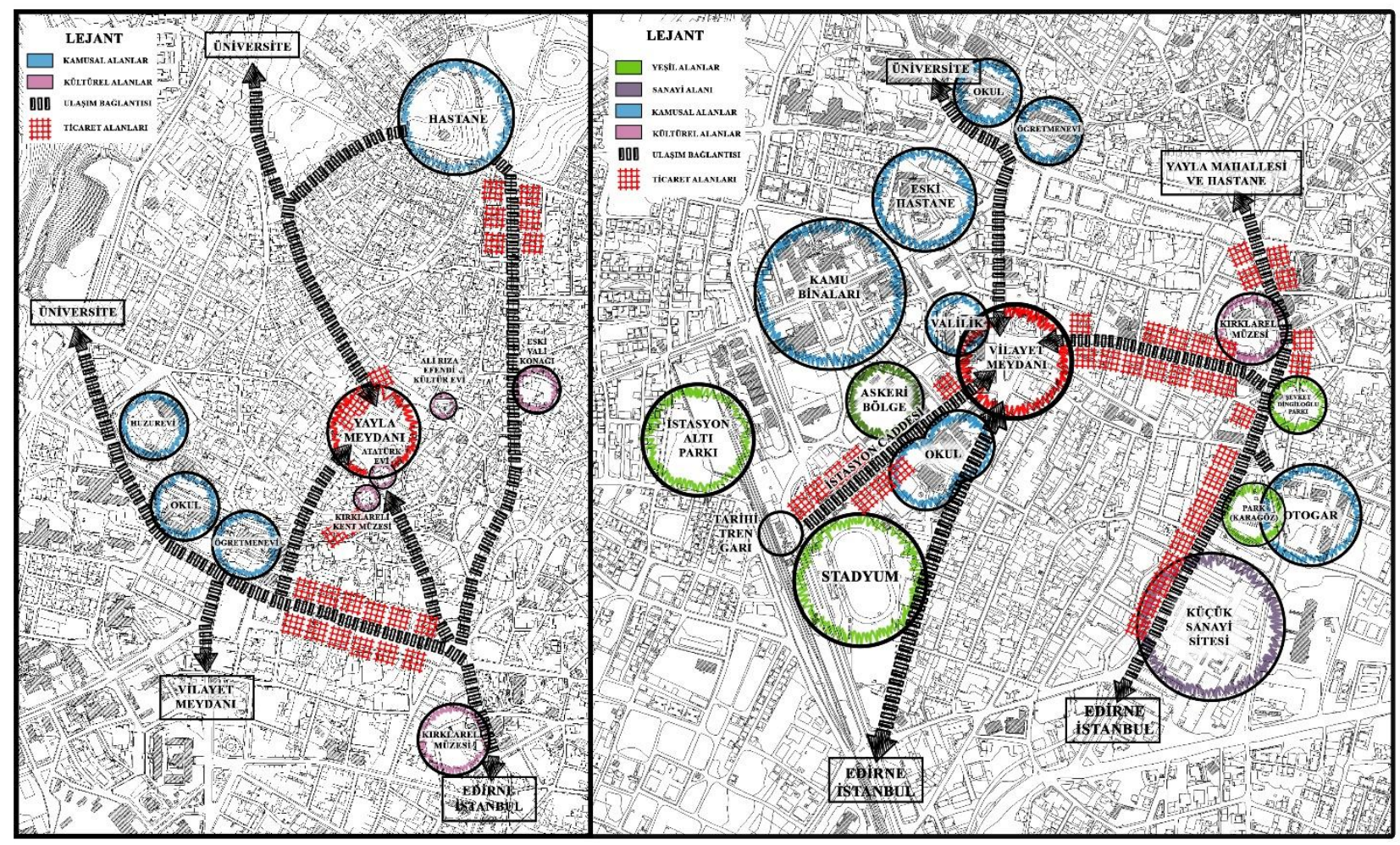

Şekil 9. Yayla ve Vilayet Meydanları Çevresel İlişkiler

İnsan-Mekân Etkileşimi Bağlamında Kırklareli Merkez Yayla ve Vilayet Meydanları Kullanılabilirlik Durumunun Araştırılması

Journal of Urban Academy | Volume: 13 Issue: 2 Yaz 2020 | ISSN: 2146-9229 


\section{BULGULAR}

\subsection{Mekânsal Analiz, Gözlem ve Sayım Sonuçlarının Değerlendirilmesi}

Erişilebilirlik-Bağlantılılık niteliği öncelikle bağlantı olanakları alt başlı̆̆ı ile değerlendirmiştir. Yayla Meydanı 3 cadde ve 2 sokak ile bağlantılıdır. Vilayet Meydanı ise 3 ana cadde ve 6 sokak ile bağlantılıdır. Yayla Meydanı Vilayet Meydanına göre daha az merkezidir. Vilayet Meydanı bağlantı olanakları açısından ana yollara doğrudan erişebilen nitelikte merkezi bir konum özelliği göstermektedir. Vilayet Meydanı Yayla Meydanına göre bağlantılılık açısından daha fazla erişime imkân vermektedir. Erişilebilirlikte yaya ulaşımı açısından Yayla Meydanına doğrudan erişimde süreklilik sağlanmış, yaya kullanım alanları oluşturulmuştur (Şekil 10). Vilayet Meydanı bir kavşak özelliği göstermesi nedeni ile araç yolları ile bölünmektedir ve yaya sürekliliği sağlanamamıştır. Vilayet Meydanına toplu taşıma ile şehrin her noktasından ulaşmak mümkündür. Yayla Meydanına en yakın mesafeye sadece bir toplu taşıma aracı belli bir güzergâhtan hizmet vermektedir. Vilayet Meydanı merkez alanda, özel araç tercihi daha yoğun olan bir bölgededir. Yayla Meydanı ziyaretçi ve kullanıcıları için yürünebilir ve gezilebilir bir alan olma özelliği ile özel araç tercihi daha azdır. Vilayet Meydanında boş otopark bulmak çok zordur. Vilayet Meydanındaki otopark alanları toplam 45 adet araç kapasitelidir ve kullanım yoğunluğuna göre yeterli değildir. Yayla Meydanında otopark düzenlemesi bulunmaktadır ve 46 araç kapasitesi vardır. Hafta sonları ziyaretlerin artması ile yoğun araç bulunduğu zamanlarda Yayla mahallesindeki otoparkta yetersiz kalmaktadır. Engelliler için her iki meydanda da yeterli düzenleme (yol üstü has has yol ayrımı, rampa kullanımı) bulunmamaktadır. Var olan düzenlemeler ise engelli erişimine uygun değildir.
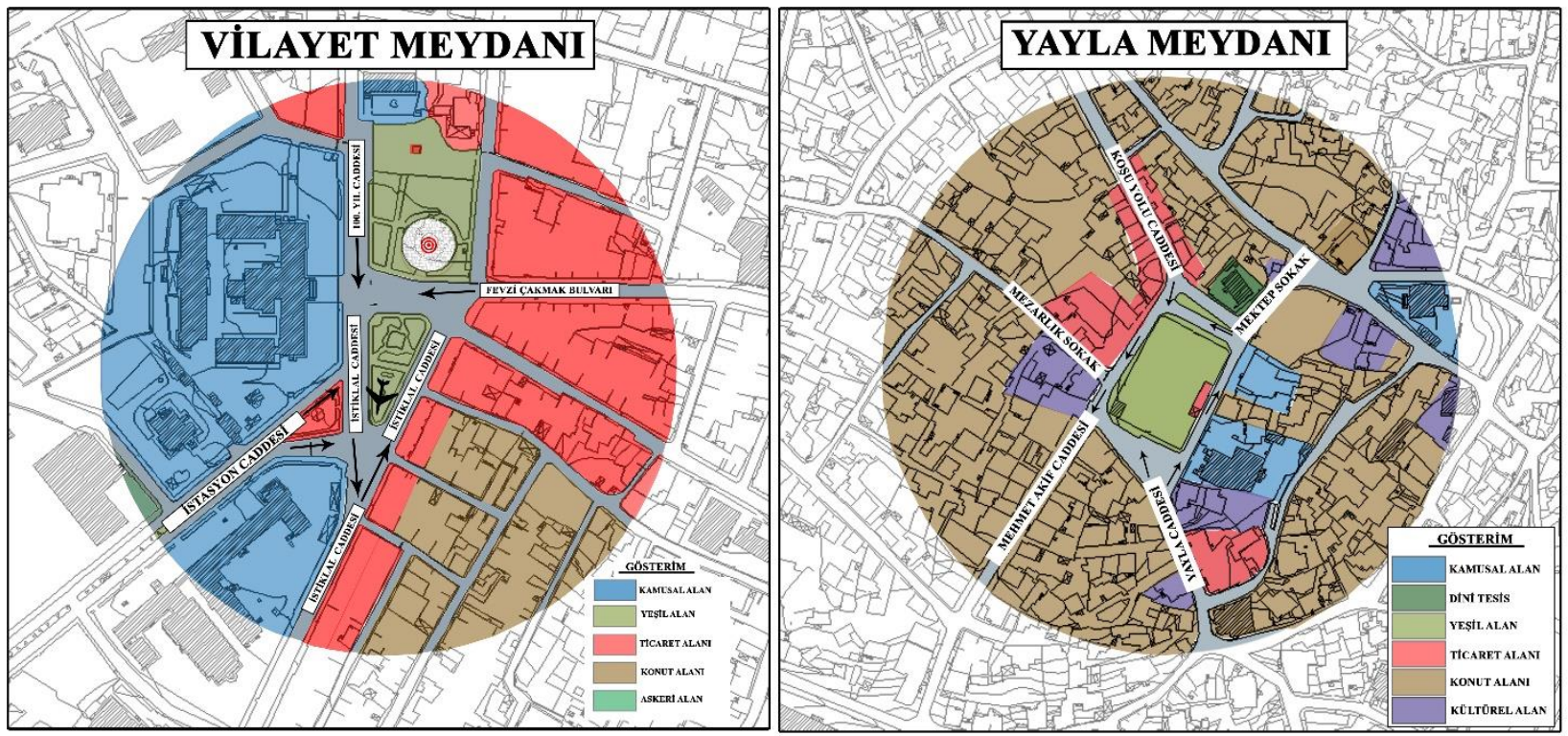

Şekil 10. Erişilebilirlik-Bağlantılık

Sosyalleşme ortamı niteliği için gözlemle yapılan değerlendirmelerde tercih eden kullanıcı tipi yaş aralıklarına göre değerlendirilmiştir. Meydan alanlarında yapılan sayımlarla mevcut kullanım, meydanların kullanım kapasiteleri ile karşılaştırılmıştır. "Alan Büyüklüğü” ölçütü için kişi başı $3 \mathrm{~m} 2$ alan alınmıştır [15]. Meydanların alan büyüklükleri hesaplanmıştır. Hesaplanan alan büyüklükleri 3'e bölünerek alanın kişi kapasitesi belirlenmiştir. Yayla Meydanının alan büyüklüğ̈̈: $3052 \mathrm{~m} 2$ dir. Vilayet Meydanının alan büyüklüğü 9245 m2dir. Yayla Meydanı 1017 kişi kapasitesine sahiptir. Vilayet Meydanı 3081 kişi kapasitesine sahiptir. Sayım sonuçları bölümünde görüldüğü üzere iki meydanın hareket halindeki yaya sayım ve taşıt sayımına göre, iki meydanda da akşam saatlerinde yoğunluk yaşanmaktadır. Vilayet Meydanı merkezi konumu ve erişilebilirlik açısından elverişli olanaklara sahip, Yayla Meydanı ile karşılaştırıldığında daha yoğun bir meydandır (Tablo 3). Meydanlarda oturan kişi sayımı meydanların kapasiteleri altında bir kullanım olduğunu göstermektedir (Tablo 4). Yapılan sayım değerlerine ve gözlemlere göre her iki meydanda da gece kullanımı vardır. Yapılan gözlemlerde her iki meydan ve çevresinde sokak hayatı canlılığı olduğu tespit edilmiştir. Yayla Meydanında daha çok aileler, Vilayet Meydanında ise yetişkin, genç nüfustan arkadaş grupları

İnsan-Mekân Etkileşimi Bağlamında Kırklareli Merkez Yayla ve Vilayet Meydanları Kullanılabilirlik Durumunun Araştırılması

Journal of Urban Academy | Volume: 13 Issue: 2 Yaz 2020 | ISSN: 2146-9229

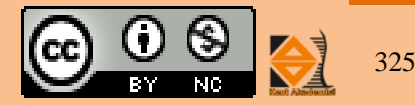


ve bu bölgede yaşayan aileler ağılıklıdır. Hem gece hem gündüz kullanıcı varlığı ile iki meydanda da sosyal ilişkiler yoğun olarak hissedilmektedir.

Kullanım ve Aktivite olanaklarında meydan kullanımında kullanıcılar için tercih nedeni olan kamusal alan yeterliliği, kentsel donatı alanlarına yakınlık, günlük ticaret alanlarına erişime bakılmıştır. Yayla Meydanında kamusal alanların daha fazla olduğu, ancak günlük ticari ihtiyaçların karşıllanmasında Vilayet Meydanı ve çevresinin erişilebilir nitelikte olduğu, Yayla meydan ve çevresinin buna izin vermediği, kentsel donatı alanlarına erişilebilirlik açısından da Vilayet Meydanının daha merkezi bir konumda olduğu tespit edilmiştir (Şekil 9). Aktivite çeşitliliği açısından Vilayet Meydanı ve çevresinin hem genç ve çocuk nüfusuna hitap eden stadyum, lunapark, festival alanı, eski garla birlikte kullanılmayan tren yolu ve gezinti alanlarına yakınlığı, hem de yetişkin ve yaşlı nüfus için çay bahçeleri ve yemek yeme yerleri ile daha çok imkâna sahip olduğu görülmüştür. Yayla Meydanında ise daha çok belirli bir yaşın üzerinde aktivite alanlarının bulunduğu gözlemlenmiştir. Tarihi çevrelerin çekici niteliğinin kullanımdaki etkisi düşünülerek bu bölgelere yakınlığa bakılmıştır. Yayla Meydanının sit alanı içinde bulunması, kimlikli yapılarla çevrilmiş olması ve kent müzelerinin varlığı olumlu olarak değerlendirilmiştir. Yayla Meydanında yerel iş sahipliğine (kadınların yemek ve el becerilerini, yaptıkları hediyelik eşyaları satabildikleri alanlar) imkân veren şekilde düzenlenmiş olduğu ve Vilayet Meydanında ise yerel iş sahiplerine ilişkin bir düzenleme olmadığı tespit edilmiştir (Şekil 11).

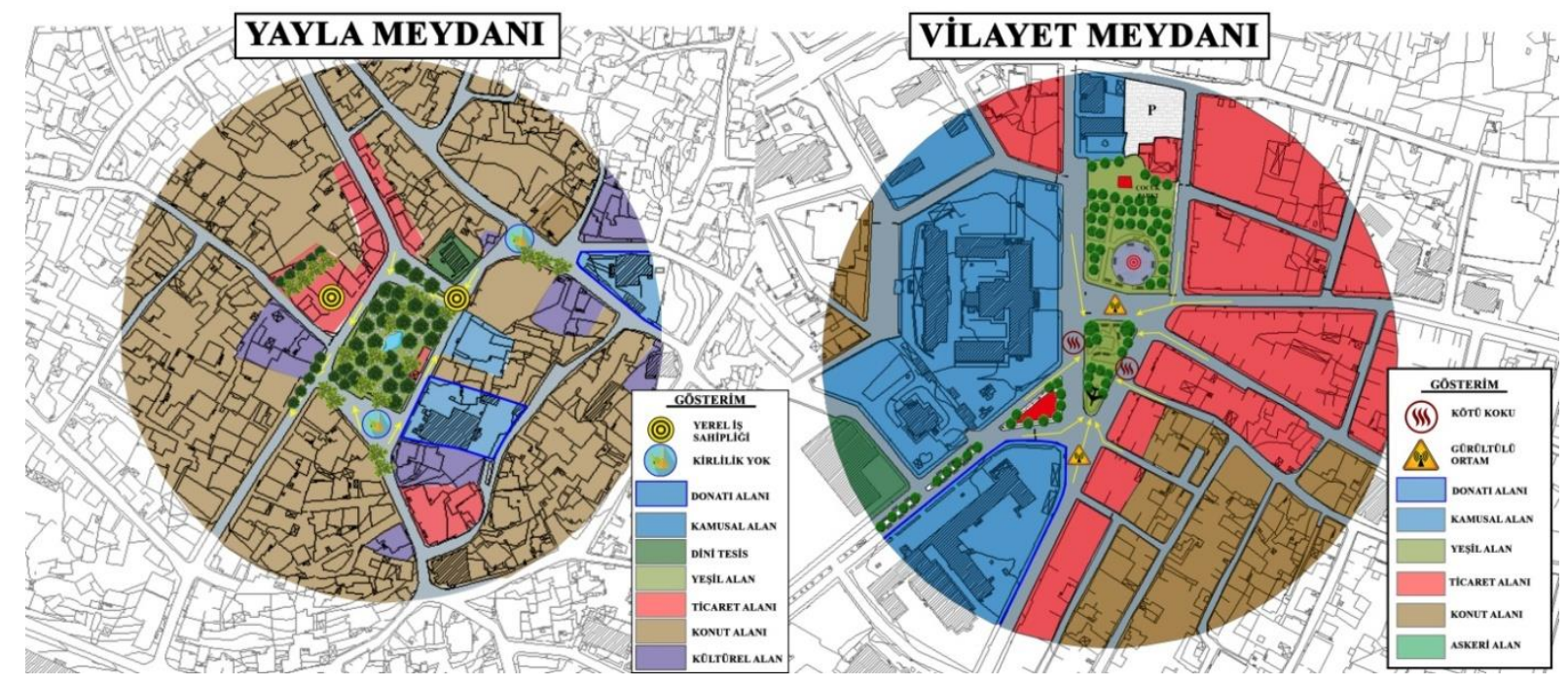

Şekil 11. Kullanım ve Aktivite Olanakları

Konfor ve imaj başlığı altında, meydanın iyi izlenim bırakması, ortamda bulunma isteğinin önemi kimlikli yapı varlığı, güvenlik hissinin varlığı için gece - gündüz kullanım durumu ve kötü koku, gürültülü ortam, kirlilik ve olumsuz görüntü parametreleri ile konfor durumuna bakılmıştır. Sosyalliği arttırabilecek meydan çevresi görsel bütünleşme etkisi yapı bütünlüğü ve yapı çevresi bütünlüğü ile araştırılmış, ayrıca alanda bulunma isteğinde olumlu etkideki açıklık-kapalılık hissi analiz edilmiştir (Şekil 12). Yayla Meydanının kimlikli yapı varlığı meydanda ilk izlenim için olumlu etkidedir. Ayrıca yapı ve yapı çevreleri bütünleşme özelliği göstermekte oturma mekânları seçime izin vermektedir. Vilayet Meydanı ise iki ana yolla bölünmüş̧ür, trafik ve yaya yoğunluğu olmasına rağmen daha çok geçiş alanı olarak kullanılmakta, var olan oturma bölgeleri Yayla Meydanına göre daha az kullanılmaktadır. Yapılan sayımlara göre her iki meydan da gece-gündüz kullanımı olan meydanlardır. Kent sokaklarında ve kent parklarında geç saatlere kadar sosyal yaşamın devam ettiği gözlemlenmiştir. Yapılan sayımlardan da anlaşılacağı üzere meydanlarda gece-gündüz kullanıcı varlığı bulunmaktadır, geceleri meydanların daha yoğun olarak kullanıldığı tespit edilmiştir. Güvenlik sorunu bulunmamaktadır. 


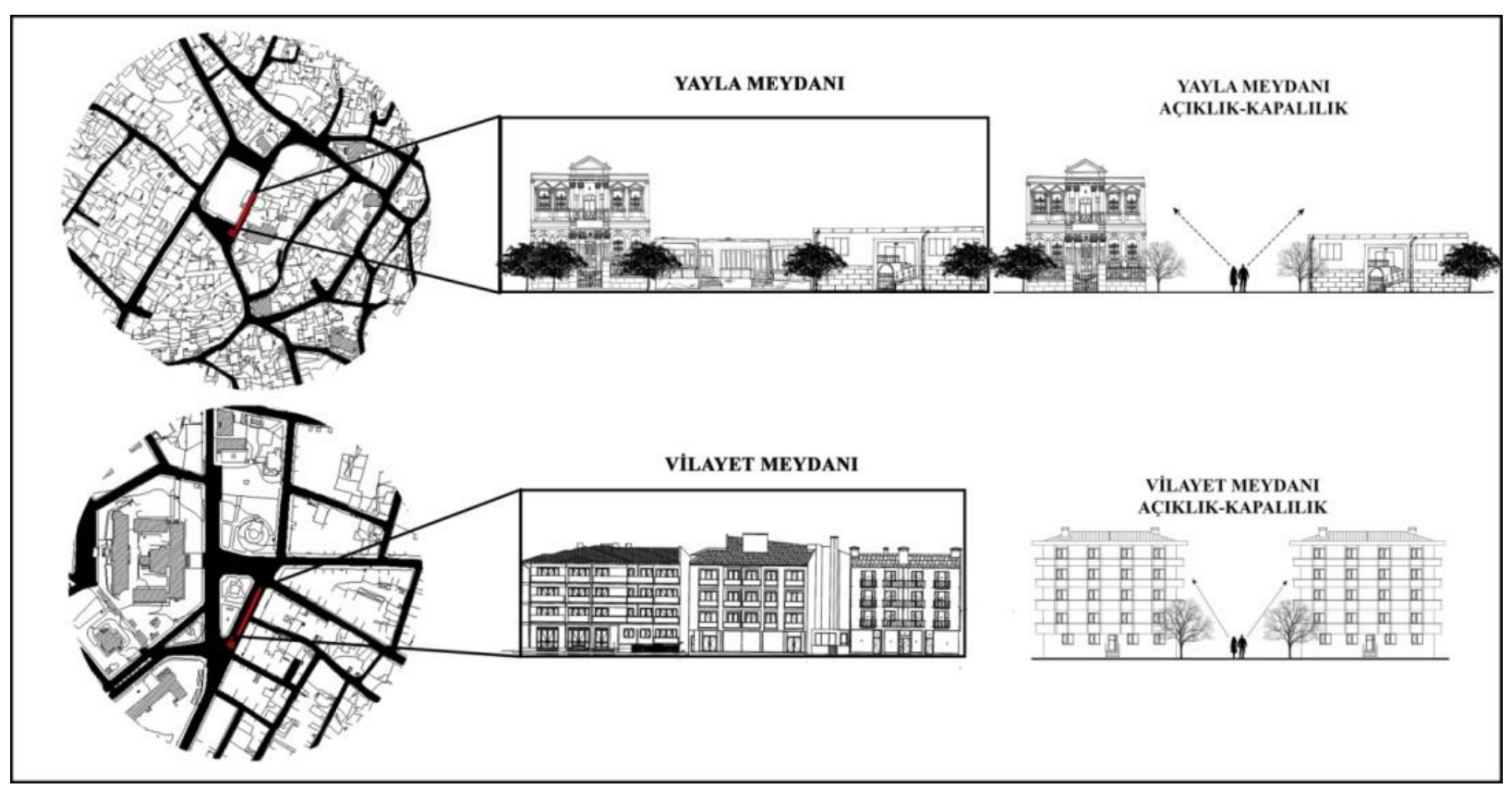

Şekil 12. Meydanlarda Yapı Ve Yapı Çevresi Bütünleşmesi, Açıklık-Kapalılık

\subsubsection{Sayım Sonuçları}

Her iki meydanda da kullanım farklarının sayısal olarak değerlendirilebilmesi için sabah, öğle, akşam birer saat süre boyunca araç ve yaya sayımı yapılmıştır. Hafta içi ve hafta sonu kullanım farklarını ortaya çıkarmak amacıyla hafta içi ve hafta sonu olmak üzere iki gün yapılmıştır.

Araç ve yaya sayımlarının hangi bölgelerde yapıldığı ve araç yönleri Yayla ve Vilayet meydanlarının hali hazırları üzerinde gösterilmiştir (Şekil 12-13). Vilayet Meydanında 3 noktada 7 yönde araç sayımı ve 4 noktada 9 yönde yaya sayımı yapılmıştır. Yayla Meydanında ise 3 noktada 7 yönde araç ve yaya sayımı yapılmıştır.

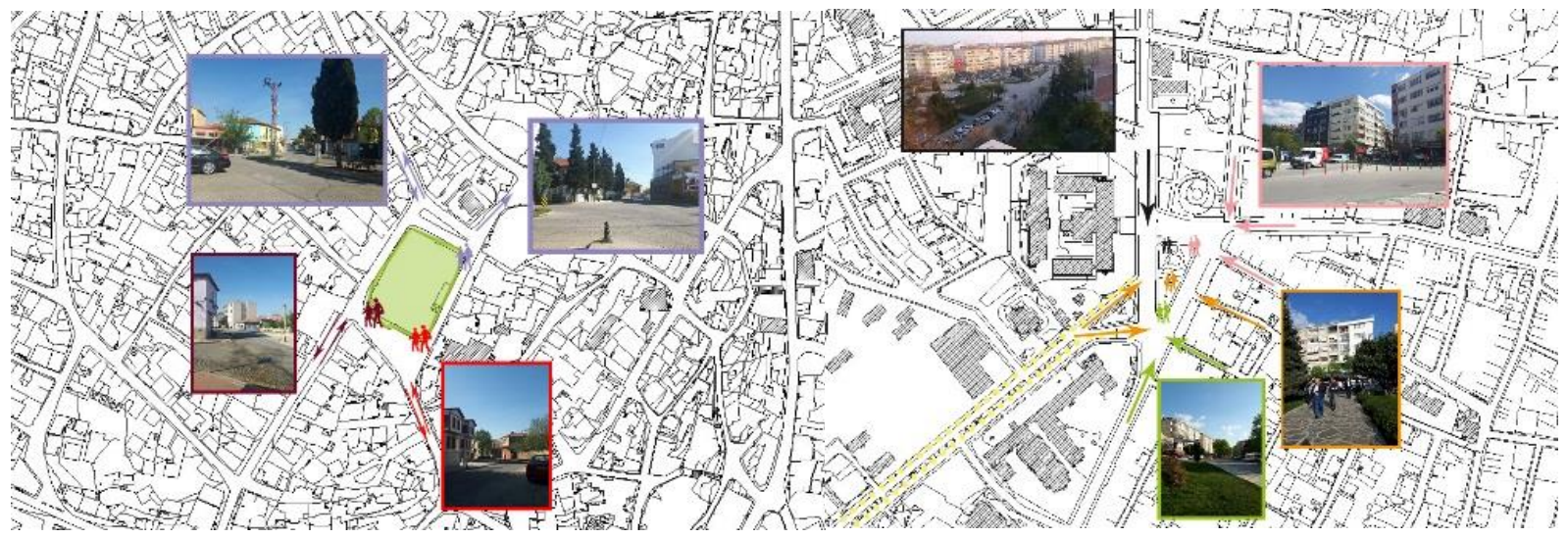

Şekil 12. Yayla Ve Vilayet Meydanlarında Yaya Sayım Yerleri (Yazarlar tarafından hazırlanmışı̧ır) 


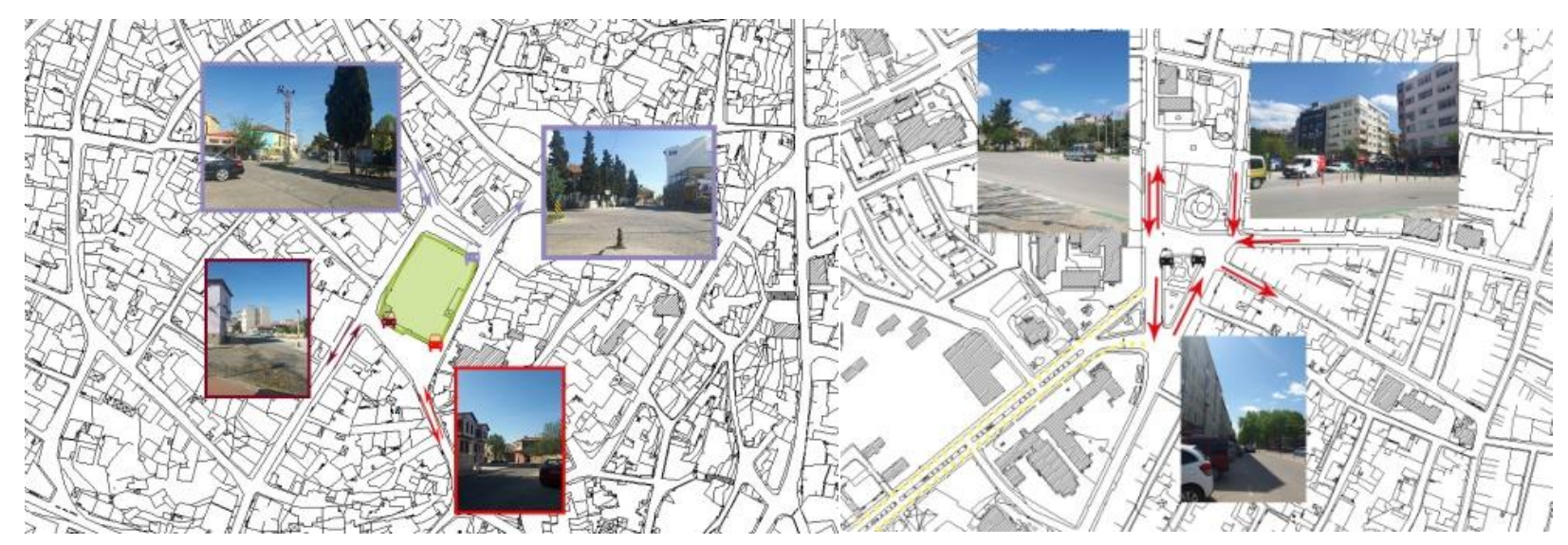

Şekil 13. Yayla Ve Vilayet Meydanları Araç Sayım Yerleri

Yayla ve Vilayet meydanlarında hafta içi ve hafta sonunda yapılan sayım sonuçlarına bakıldığında;

- $\quad$ Her iki meydanda hafta sonu yaya ve araç yoğunluğu fazladır.

- $\quad$ Her iki meydanda da araç ve yaya yoğunluğu akşam daha fazladır.

- Vilayet Meydanı her saatte Yayla Meydanından daha kalabalıktır. (Tablo 3)

Tablo 3. Yayla Ve Vilayet Meydanları Hafta İçi Ve Hafta Sonu Yaya-Araç Sayım Sonuçları

\begin{tabular}{|c|c|c|c|c|c|c|c|}
\hline \multicolumn{4}{|c|}{ YAYLA MEYDANI } & \multicolumn{4}{|c|}{ VILLAYET MEYDANI } \\
\hline & & YAYA & ARAÇ & & & YAYA & ARAÇ \\
\hline \multirow{3}{*}{ 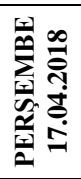 } & $S A B A H$ & 320 & 256 & \multirow{3}{*}{ 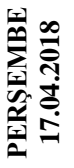 } & $S A B A H$ & 1852 & 836 \\
\hline & $\ddot{\partial G ̆ L E}$ & 408 & 312 & & $\ddot{O} \tilde{G} L E$ & 4668 & 1888 \\
\hline & AKŞAM & 764 & 400 & & AKŞAM & 5604 & 1940 \\
\hline \multirow{3}{*}{ 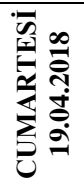 } & $S A B A H$ & 160 & 192 & \multirow{3}{*}{ 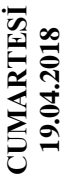 } & $S A B A H$ & 1372 & 1108 \\
\hline & $\ddot{\partial} \breve{G} L E$ & 848 & 356 & & $\ddot{O} \breve{G} L E$ & 3524 & 1672 \\
\hline & AKŞAM & 1520 & 492 & & AKŞAM & 6332 & 1788 \\
\hline
\end{tabular}

Yayla ve Vilayet meydanlarında hafta içi ve hafta sonunda yapılan oturan sayım Yayla Meydanı kentin en eski meydanı özelliğini taşımaktadır. Merkezinde daha önceleri halkın buluşma alanı olan bir park bulunmaktadır. Bu park meydan özelliği taşımaktadır. Sonuçlarına bakıldığında hafta sonunda her iki meydanında daha kalabalık olduğu, hafta içi yoğunluğunun Vilayet Meydanında hafta sonu yoğunluğunun ise Yayla Meydanında olduğu anlaşılmaktadır (Tablo 4). 
Tablo 4. Yayla Ve Vilayet Meydanları Oturan Sayısı

\begin{tabular}{|c|c|c|c|c|c|}
\hline \multicolumn{6}{|c|}{ OTURAN SAYISI } \\
\hline \multicolumn{3}{|c|}{ YAYLA MEYDANI } & \multicolumn{3}{|c|}{ VILAYET MEYDANI } \\
\hline \multirow{3}{*}{ 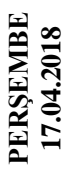 } & $S A B A H$ & 53 & \multirow{3}{*}{ 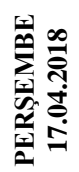 } & $S A B A H$ & 35 \\
\hline & $\ddot{O} \breve{G} L E$ & 81 & & $\ddot{O} \breve{G} L E$ & 97 \\
\hline & AKŞAM & 153 & & AKŞAM & 159 \\
\hline \multirow{3}{*}{ 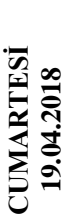 } & $S A B A H$ & 72 & \multirow{3}{*}{ 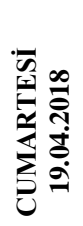 } & $S A B A H$ & 62 \\
\hline & $\ddot{O} \breve{G} L E$ & 161 & & $\ddot{O} \breve{G} L E$ & 94 \\
\hline & AKŞAM & 231 & & AKŞAM & 223 \\
\hline
\end{tabular}

Mekânsal analiz, gözlem ve sayım sonuçlarına göre iki meydan için yapılan değerlendirme Tablo 5 'te görülmektedir. Dört anahtar başlık altında 27 adet ölçme kriteri ile belirlenen kullanılabilirlik durumu değerlendirmelerine göre Yayla Meydanında 20, Vilayet Meydanında ise 14 kriterde yeterlilik olduğu tespit edilmiştir (Tablo 5).

Tablo 5. Yayla ve Vilayet Meydanları Kullanılabilirlik Durumu Değerlendirmesi

\begin{tabular}{|c|c|c|c|c|}
\hline \multirow{2}{*}{ 兰 } & \multicolumn{2}{|c|}{ Meydanların Birbirlerine Göre Durumu|Değerlendirme Kriterleri } & Yayla & Vilayet \\
\hline & \multicolumn{4}{|l|}{ Bağlantı Olanakları } \\
\hline \multirow{9}{*}{ 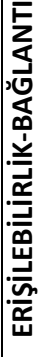 } & Anayol Bağlantıııığı & Doğrudan-Değil & 0 & 1 \\
\hline & Tali Yol Bağlantılılığı & Doğrudan-Değil & 1 & 1 \\
\hline & Erişilebilirlik & & & \\
\hline & Ulaşım Alternatifleri & & & \\
\hline & Yaya Ulaşımı & Kesintisiz-Süreksiz & 1 & 0 \\
\hline & Toplu Taşıma & Yeterli-Yetersiz & 0 & 1 \\
\hline & Özel Araç Tercihi & Az Yoğun-Yoğun & 1 & 0 \\
\hline & Otopark Yeterliliği & Yeterli-Yeterli Değil & 1 & 0 \\
\hline & Engeliler için düzenleme & Var-Yok & 0 & 0 \\
\hline \multirow{5}{*}{ 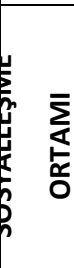 } & & Değerlendirme Kriterleri & Yayla & Vilayet \\
\hline & Tercih Eden Kullanıcı & $\begin{array}{c}\text { Yoğunluğa Göre Karşılaştırma } \\
\text { Kişi/Kapasite }\end{array}$ & 0 & 0 \\
\hline & Gece Kullanımı & Var-Yok & 1 & 1 \\
\hline & Sokak Hayatı Canlılığı & Var-Yok & 1 & 1 \\
\hline & Sosyal Ağ ve iliş̧kiler & Var-Yok & 1 & 1 \\
\hline \multirow{7}{*}{ 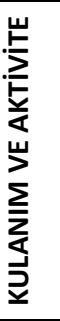 } & & Değerlendirme Kriterleri & Yayla & Vilayet \\
\hline & Kamusal Alan Yeterliliği & Yeterli-Değil & 1 & 0 \\
\hline & Donatı Alanlarına Yakınlığı & Yakın-Değil & 1 & 1 \\
\hline & Gün. Tic. Alanlarına Erişim & Yakın-Değil & 0 & 1 \\
\hline & \multicolumn{4}{|c|}{ ¿̨YYakınlıklar yürüme (5 dakika) mesafesi ile değerlendirilmiştir. } \\
\hline & Yerel İş Sahipliği & Var-Yok & 1 & 0 \\
\hline & Aktivite Çeşitliliği & Çok-Az & 0 & 1 \\
\hline \multirow{5}{*}{ 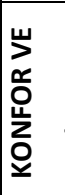 } & & Değerlendirme Kriterleri & Yayla & Vilayet \\
\hline & Kimlikli Yapı Varlığı & Var-Yok & 1 & 0 \\
\hline & Eece-Gündüz Kullanımı & Var-Yok & 1 & 1 \\
\hline & Çevresel Kalite & & & \\
\hline & Kötü Koku & Yok-Var & 0 & 0 \\
\hline
\end{tabular}




\begin{tabular}{|c|c|c|c|}
\hline Olumsuz Görüntü & Yok-Var & 1 & 0 \\
\hline Gürültülü Ortam & Yok-Var & 1 & 0 \\
\hline iklimsel Olumsuzluk & Yok-Var & 1 & 1 \\
\hline Kirlilik & Yok-Var & 1 & 1 \\
\hline \multicolumn{4}{|l|}{ Görüş Alanı } \\
\hline Açıklık - Kapalılık Hissi & Açıklık-Kapalılık & 1 & 1 \\
\hline Görsel Bütünlük & Yok-Var & 1 & 0 \\
\hline Yapı & Var-Yok & 1 & 0 \\
\hline Yapı ve Çevresi & Var-Yok & 1 & 0 \\
\hline
\end{tabular}

\subsection{Anket Sonuçlarının Değerlendirilmesi}

Çalışmanın bu bölümünde kullanıcı anketlerinin meydan kullanım durumu, nedenleri, talep ve ihtiyaçlarının belirlenebilmesi bölüm sonuçları değerlendirilmiştir.

Kullanıcılar kullanım durumlarına ilişkin "günde ortalama kaç saatlerini Yayla/Vilayet Meydanında geçiyorsunuz?, Genel olarak günün en çok hangi saatlerinde kullanıyorsunuz? Sorularına verilen cevaplar aşağıda belirtilmiştir.
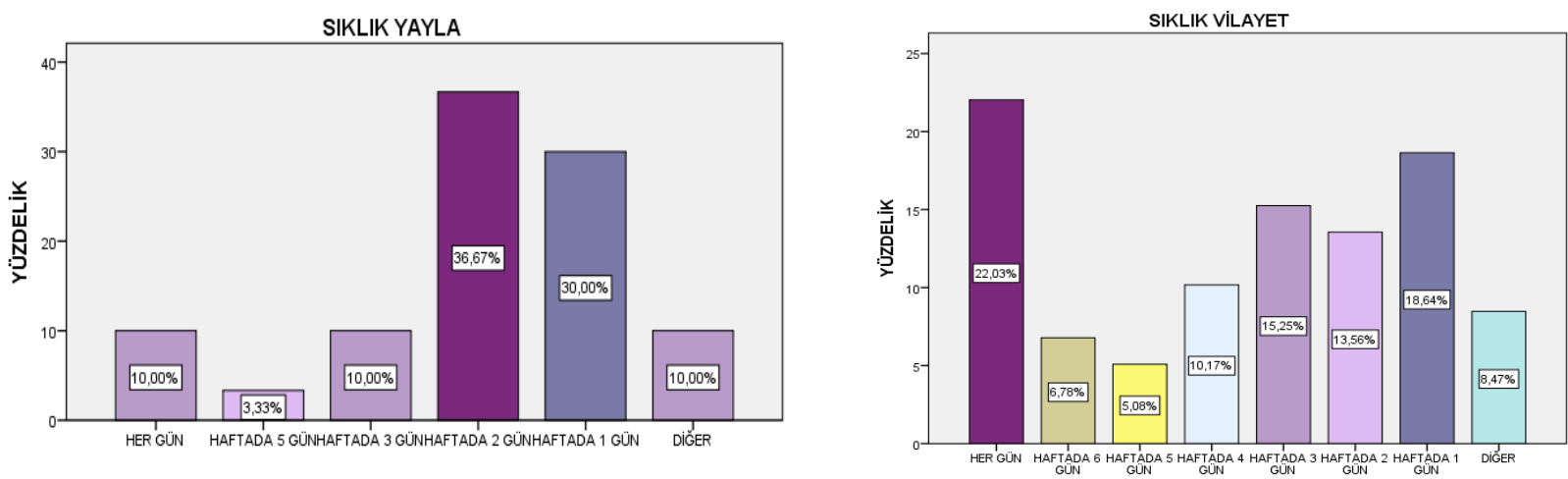

Şekil 14. Kullanım Sıklığı

Yayla Meydanında yapılan anketlerde çoğunluğun haftada 2 gün, Vilayet Meydanında yapılan anket sayısında çoğunluğun her gün cevabı verdiği görülmektedir.
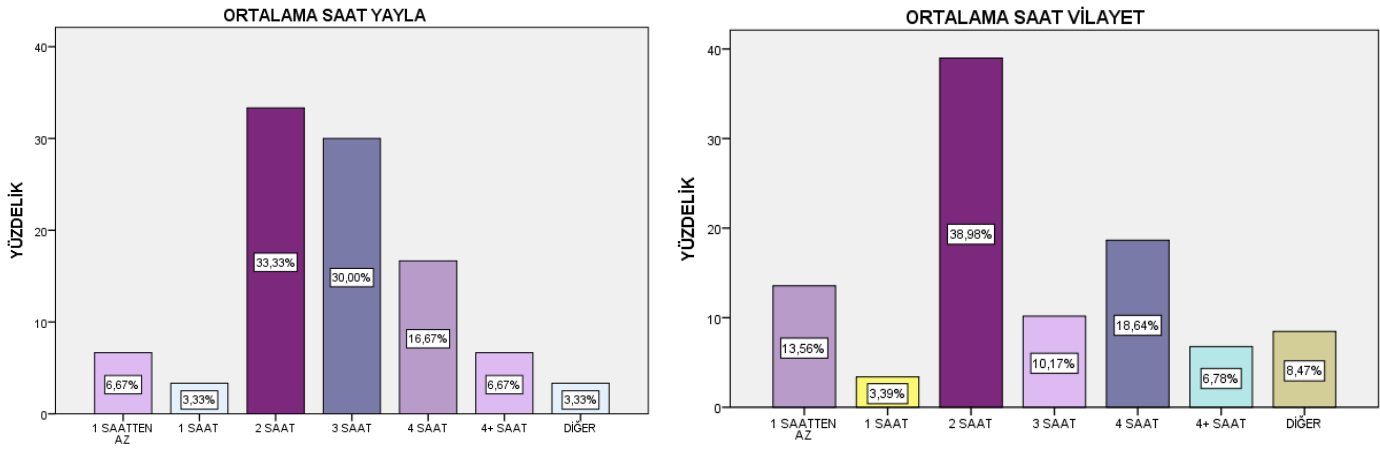

Şekil 15. Ortalama Kullanım Saati 
Vilayet ve Yayla meydanlarının ortalama kullanım saatlerine bakıldığında; her iki meydanda ortalama kullanım sıklığının daha yüksek oranda 2 saat olduğu görülmektedir (Şekil 15).
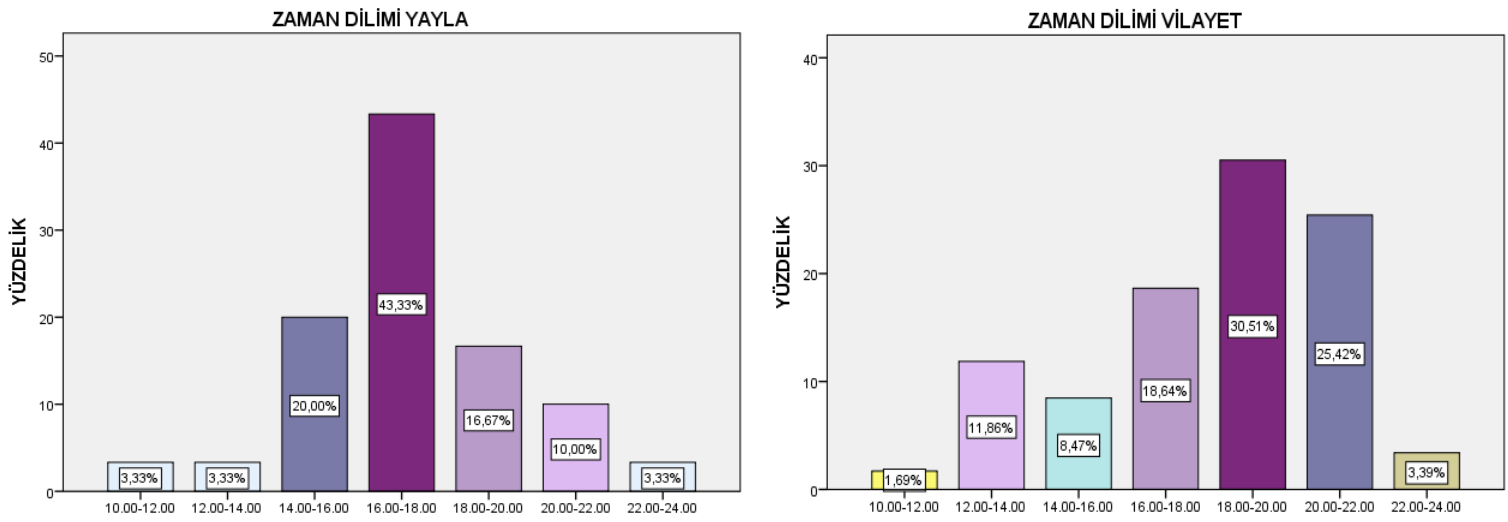

Şekil 16. Kullanımı Zaman Dilimi

Vilayet ve Yayla meydanlarının ortalama hangi zaman dilimlerinde kullanıldığına bakıldığında; Yayla Meydanının en çok 16.00 ve 18.00 zaman diliminde kullanıldığı, Vilayet Meydanının 18.00 ile 20.00 arasında en çok kullanıldığı görülmektedir (Şekil 16).

- Yayla/Vilayet Meydanına genellikle kiminle çıkıyorsunuz? Sorusunun analiz sonuçlarına bakıldığında; Yayla Meydanı kullanıcılarının yüksek oranda "aile" cevabı verdiği görülmektedir. Vilayet Meydanı kullanıcılarının daha yüksek oranda "arkadaşlar" cevabı verdiği görülmektedir (Şekil 17).
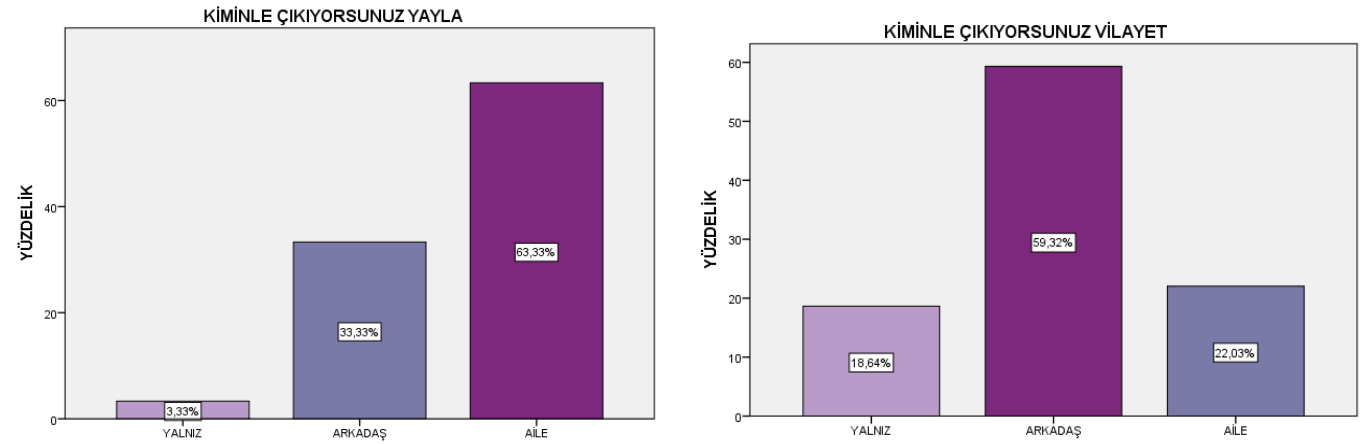

Şekil 17. Kim/Kimlerle Birlikte Bulunulduğu

- Yayla/Vilayet Meydanı “kullanım nedenleriniz nelerdir?” sorusunun analiz sonuçlarına bakıldığında;

Yayla Meydanının da dinleme amaçlı ve gezinti amaçlı kullanım olduğu görülmektedir. Vilayet Meydanının sosyalleşmek, dinlenmek ve alışveriş yapma öncelikli kullanıldığı görülmektedir (Şekil 18). 

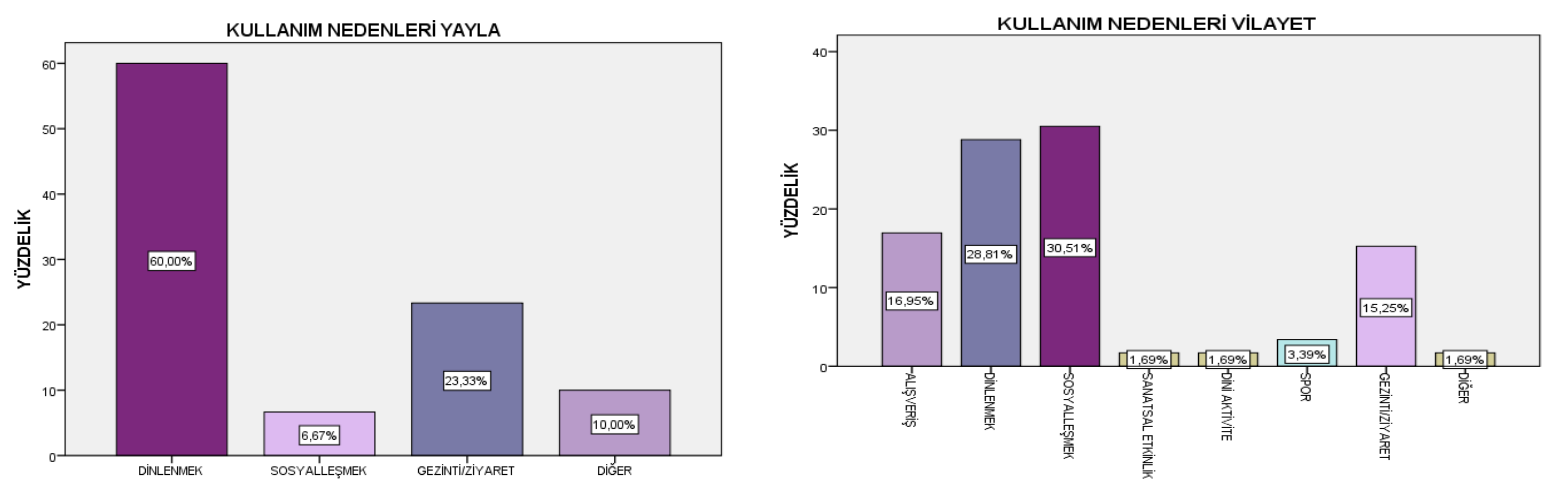

Şekil 18. Kullanım Nedenleri

- Yayla/Vilayet Meydanında yeterli çeşit ve nitelikte kamusal mekânlar mevcut mu? Sorusunun analiz sonuçlarına bakıldığında; Yayla Meydanı için \%66,67 oranında, Vilayet Meydanı için \% 62,71 oranında, yeterli olduğu belirtilmiştir.

- Yayla/Vilayet Meydanındaki yeşil alanlar (park, oyun parkı vb.) yeterlimi? Sorusunun analiz sonuçlarına bakıldığında; Yayla Meydanında \% 67.66 oranında, Vilayet Meydanında \% 66,10 oranında yeterli olduğu belirtilmiştir.

- Kullanıcı memnuniyetine ilişkin yayla/Vilayet Meydanı memnuniyeti sorusunun analiz sonuçlarına göre; Yayla Meydanının Vilayet Meydanına göre daha temiz bulunduğu ortaya çıkmıştır (Şekil 19).
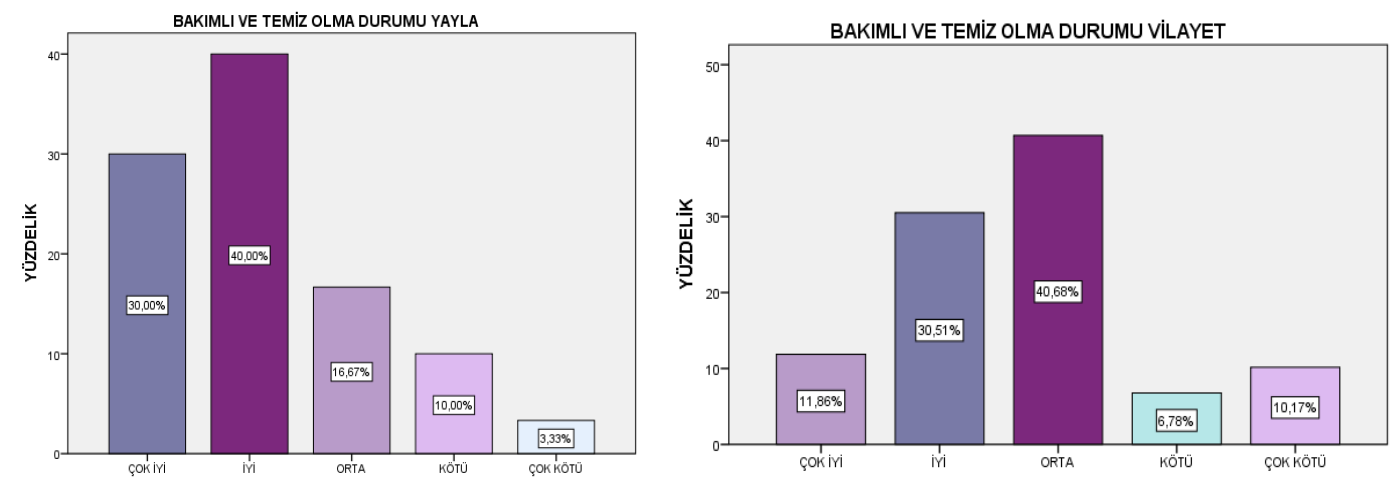

Şekil 19. Bakımlı ve temiz olma durumu 

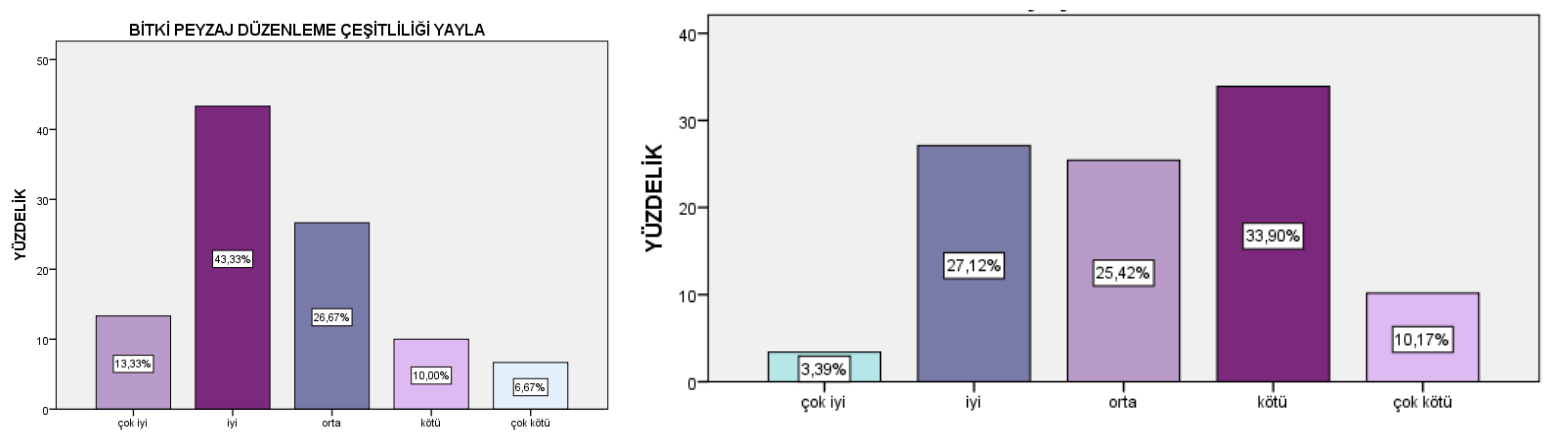

Şekil 20. Bitki Peyzaj Düzenleme Çeşitliliği

- Kullanıcılar memnuniyet bölümünde sorulan bitki peyzaj düzenleme çeşitliliği için Vilayet Meydanı peyzaj düzenlemesini daha yüksek oranda kötü olarak değerlendirilirken, Yayla Meydanının peyzaj düzenlemesinin yüksek oranda iyi olarak değerlendirildiği görülmektedir (Şekil 20).
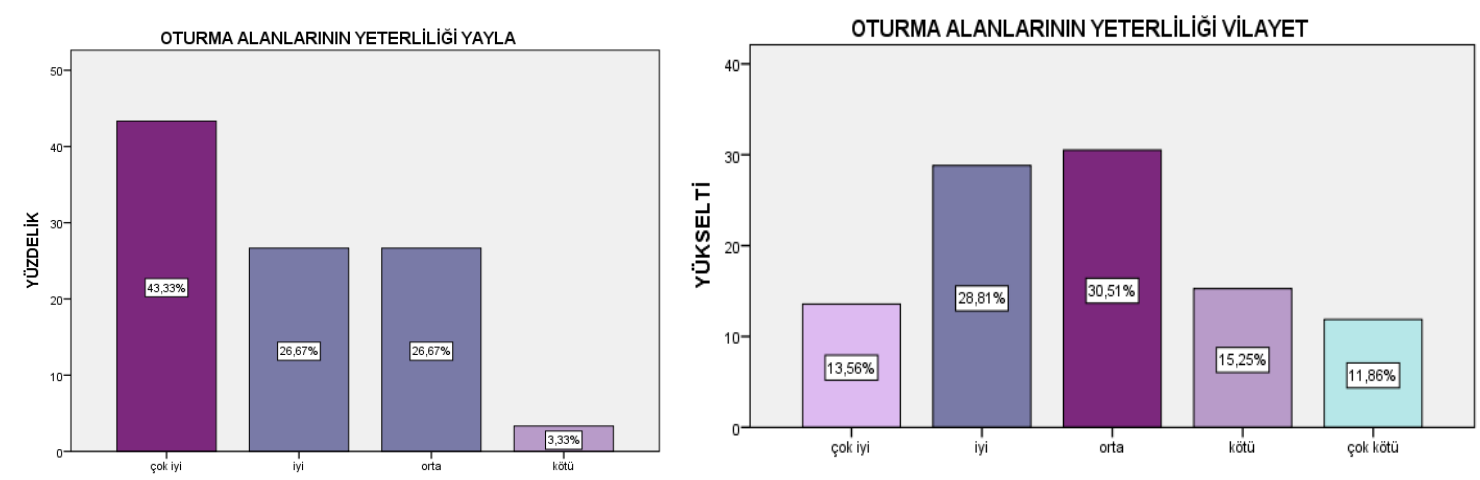

Şekil 21. Oturma Alanı Yeterliliği Analizi

- Kullanıcı memnuniyeti bölümündeki oturma alanları yeterliliği, Yayla Meydanında Vilayet Meydanına göre daha yeterli olarak değerlendirilmiştir (Şekil 21).
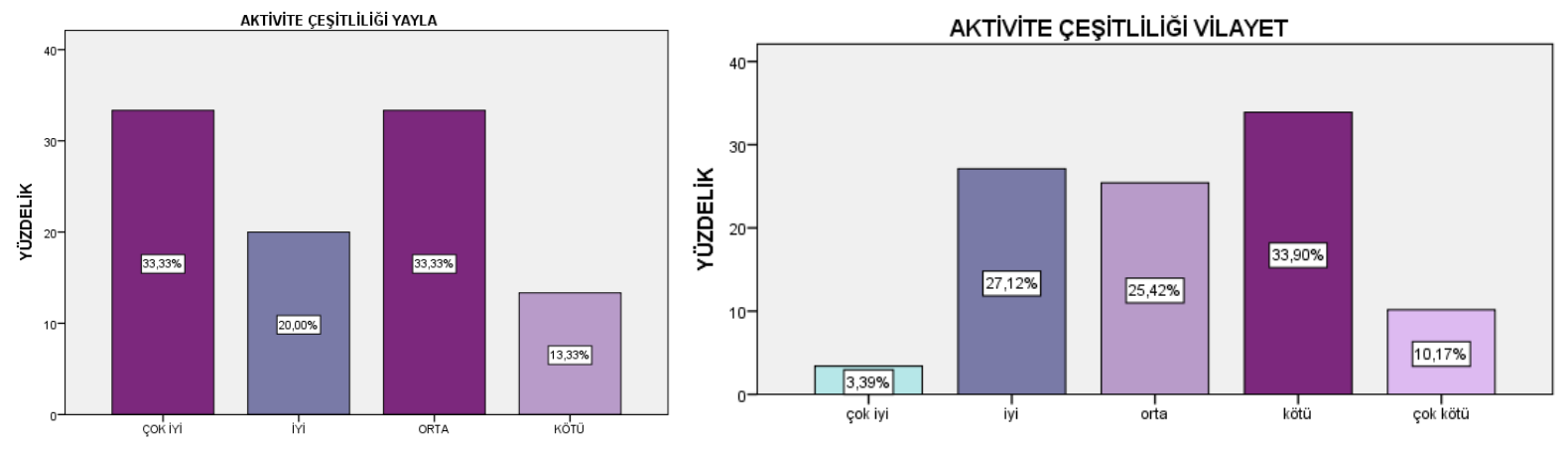

Şekil 22. Aktivite Çeşitliliği 
- Yapılan anketlerde aktivite çeşitliliği sorusuna verilen cevaplarda Yayla Meydanında büyük bir bölüm çok iyi derken, büyük bir bölümde orta cevabı vermiştir. Vilayet Meydanında aktivite çeşitliliği, en yüksek oranda kötü olarak nitelenmiştir (Şekil 22).
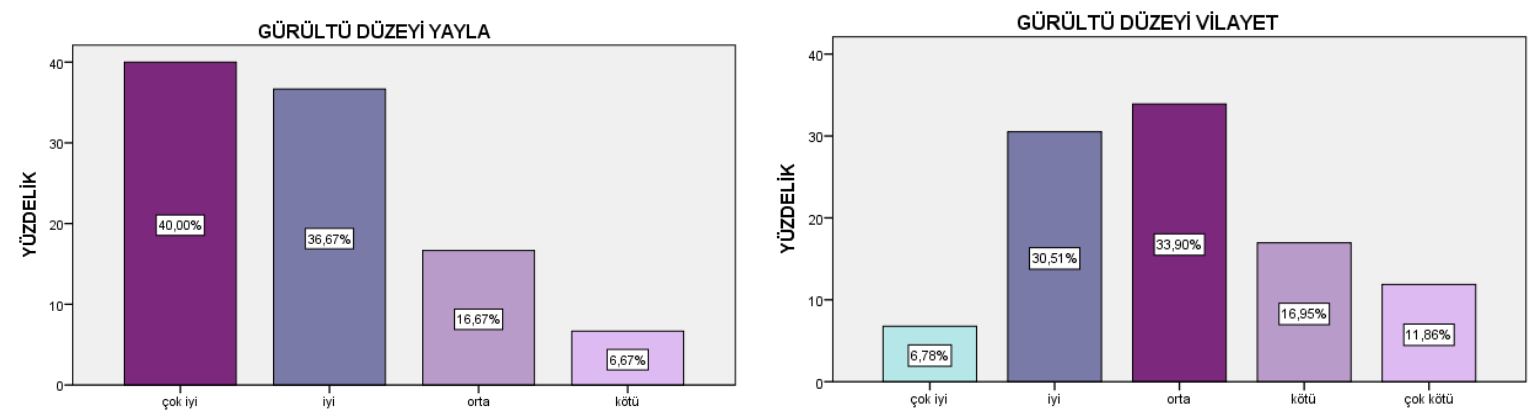

\section{Şekil 23. Meydanların Gürültü Düzeyi}

- Yayla Meydanında kullanıcıların gürültü düzeyine bakıldığında bu meydanın sakin, trafikten uzak bir alanda olması sebebi ile kullanıcıların bu meydandan çok memnun olduğu görülmüştür. Vilayet Meydanı bir kavşak meydanı ve kentin en çok kullanılan meydanı olması sebebi ile gürültü düzeyi yüksek bir meydandır. Yapılan anket sonuçlarına göre kullanıcılar Vilayet Meydanı gürültü düzeyini en yüksek oranda orta derece olarak nitelemiş, iyi ve ardından kötü olduğu şeklinde sıralanmıştır. Yayla Meydanında gürültü düzeyinin sorunsuz olduğu görülmektedir (Şekil 23).

- Kullanıcı taleplerine ilişkin anket sonuçlarına göre; "Yayla Meydanı" için meydana olan ulaşımın düzenlenmesi, meydana otobüs seferleri düzenlenmesi talebi, peyzaj düzenlemelerinin yapılması, yerel tanıtıcı ürünlerin satışa çıkartılacağı dükkânlar, yerel yemeklerin satıldığ1 yeni alanların arttırılması öncelikli olarak talep edilmiştir. Bu taleplerden sonra oturma alanlarının çoğaltılması, meydan çevresindeki cadde ve sokakların düzenlenmesi, yayalaştırılarak alanın tamamen trafiğe kapatılması, bisiklet kullanımının yaygınlaştırılması talepleri alınmıştır.

- Vilayet Meydanı için, trafiğin ve meydanın yeniden düzenlenmesi, araç yoğunluğunun azaltılması, oturma alanlarının arttırılması, aktivite alanlarının geliştirilmesi ve çoğaltılması, belli yollarda yayalaştırma yapılarak araç trafiğinin azaltılması, bisiklet yollarının yapılması öncelikli olarak talep edilmiştir. Daha sonra alışveriş merkezinin kurulması, yaya yollarının düzenlenmesi, peyzaj çalışmalarının gerçekleştirilmesi, park alanlarının çoğaltılması, daha fazla yeşil alan oluşturulması talepleri alınmıştır.

\section{TARTIŞMA}

Meydanların Kullanılabilirlik parametreleri doğrultusunda yapılan gözlem ve tespitlere göre; Vilayet Meydanı, Yayla Meydanına göre daha merkezi yol bağlantıları ile daha güçlü toplanma-dağılma ve geçiş özelliği göstermekte, Yayla Meydanı ise merkezden uzak yerel bir meydan niteliğinde toplanma özelliği göstermektedir. Vilayet Meydanı ticaret, alışveriş, dinlenme, yeme-içme gibi fonksiyonların odak noktasında ve kullanıcı kapasitesi olarak Yayla Meydanının üç katına yakın büyüklüktedir. Yayla Meydanı ise kapasitesi daha sınırlı bir meydan olmasına rağmen, sit alanı içerisinde konumlanması nedeniyle turistik anlamda müze, sergi gibi sanatsal faaliyetlerin yer aldığı dinlenme ve gezinti amaçları ile tercih edilen bir meydan olma özelliği taşımaktadır. Yayla Meydanı çevresinde iki katlı yapılarla ferahlık hissi vermekte, Vilayet Meydanında ise, kat yüksekliği altı kat ve üstüne çıkan yapılarla çevrili, ana yollarla bölünmüş, bütünlüğü sağlanamamış bir meydan olması nedeniyle tam bir kapalılık hissi bulunmamakla birlikte parçalanmışlık nedeniyle bütüncül algılama hissi bulunmamaktadır. Vilayet Meydanının çevresel kalitesi gün boyu araç ve yaya trafiğinin yoğun olması ayrıca yapılardaki uyumsuz planlama nedenleri ile görüntü, gürültü ve kirlilik açısından olumsuzdur. Yayla Meydanında çevresel kalite özelliklerinin tamamı olumludur. Yayla Meydanı içinde bulundurduğu fonksiyon ve aktivitelerle alışverişe olanak sağlamamaktadır. Vilayet Meydanı ise konumu ve içinde bulundurduğu fonksiyonlarla alışveriş imkânı sunmaktadır. Her iki meydanda yeşil alan yakınlığı açısından yeterlidir. 
Ancak Yayla Meydanı içinde bulunduğu park alanı, tarihi bölge ve tarihi ağaç varlığı ile avantajlı konumdadır. Yayla Meydanı özellikle son dönem yapılan çevre düzenleme ve restorasyon çalışmaları ile çevresi ve tarihi yapılarla bütünlük sağlamaktadır. Vilayet Meydanında ise birbiri ile uyumsuz estetik kaygı taşımayan, bitişik nizam yüksek katlı yapılaşmalarla mimari anlamda yapısal bütünlük bulunmamaktadır.

Yayla Meydanında yapılan gözlemler sonucunda meydan kullanıcı türünün yaşlı ve yetişkin grubunda yoğun olduğu, Vilayet Meydanında ise meydan kullanıcı türünün genç ve yetişkin grubunda yoğun olduğu görülmüştür. Bu yoğunluk değerlendirmesi, Yayla ve Vilayet meydan niteliklerine de paralel özelliktedir. Araç ve yaya sayımı ile seçilen meydanlarda bulunan insan ve araç sayısı ortaya çıkarılarak, meydanların kullanım yoğunluğuna bakılmıştır. Her iki meydan da hem gündüz hem akşam saatlerinde yoğundur. Bu sonuç her iki meydanında kullanım açısından aktif olduğunu göstermektedir. Kent kullanıcıları oturma, dinlenme ve sosyalleşme faaliyetlerinde aktiftir. Ayrıca oturan sayımına göre çok büyük farklılıklar olmasa da, hafta içi Vilayet Meydanını, hafta sonu ise Yayla Meydanını daha çok tercih ettikleri, ancak her iki meydanda da kapasitesinin altında kullanım olduğu tespit edilmiştir. Meydan nitelikleri düşünüldüğünde, kent kullanıcılarının hafta içi alışveriş, ticaret gibi faaliyetlere daha çok zaman, hafta sonu ise dinlenme ve gezme faaliyetlerine daha çok zaman ayırdıkları söylenebilir. Ancak bu çıkarımlar daha birçok sosyolojik ayrıntıyı içeren araştırmayı gerektirmektedir.

Meydanların kullanıcı durumu, memnuniyeti ve taleplerinin alınmasına ilişkin, Yayla Meydanında 30 kişi ve Vilayet Meydanında 60 kişi ile yapılan anket sonuçlarına göre; "meydanların ne sıklıkla kullanıldığı" sorusuna Yayla Meydanı için iki gün, Vilayet Meydanı için her gün yanıtı en fazla verilmiştir. Bu sonuç Vilayet Meydanının fonksiyonel erişilebilirlikteki merkezi konumunu ve var olmasının kent merkezi için önemini de göstermektedir.

Her iki meydanda "ortalama kullanım" süresi iki saattir. Yayla Meydanının kullanılma zaman dilimi en çok 16.0018.00 arası, Vilayet Meydanında ise 18.00-20.00 arasıdır. Kullanıcılar akşam vakitlerinde daha merkezi ve yeme-içme alanları daha yoğun olan Vilayet Meydanını tercih etmektedir. Meydanda "kimlerle birlikte bulunulduğu" sorusuna, Yayla Meydanı kullanıcılarının daha sıklıkla "aile" ile birlikte, Vilayet Meydanı kullanıcılarının daha sıklıkla "arkadaş" ile birlikte bulunma cevabı, yapılan gözlemlerle ortaya çıkan Yayla Meydanında daha büyük oranda yetişkin nüfus bulunması, Vilayet Meydanında daha büyük oranda genç nüfus bulunmasını doğrulamaktadır.

Yayla ve Vilayet meydanları kullanım nedenleri için verilen cevaplarda da, Yayla Meydanı en çok dinlenme ve gezinti amaçlıdır. Vilayet Meydanının ise sosyalleşme, dinlenme ve alışveriş yapma öncelikli olarak kullanıldığı görülmektedir. Vilayet Meydanı ile bağlanan İstasyon Caddesi kentin en önemli sosyal aktivite akslarından biridir. Anket cevaplarındaki öncelikli kullanım amacı meydanların niteliklerini yansıtmaktadır.

Yayla ve Vilayet meydanlarının yeşil alan yeterliliği ve kamusal mekânların yeterliliğine ilişkin memnuniyet sorularına kullanıcılardan her iki meydan içinde \% 60'ın üzerinde yeterli cevabı alınmıştır. Yayla ve Vilayet meydanlarının temizliği ile ilgili değerlendirilmesinde, Yayla Meydanının Vilayet Meydanına göre daha temiz bulunduğu ortaya çıkmıştır. Aynı şekilde kullanıcıların meydanların peyzaj düzenlemesini, Yayla Meydanı için çoğunlukla iyi, Vilayet Meydanı içinse çoğunlukla kötü olarak nitelendirdikleri görülmüştür. Memnuniyete ilişkin bu cevaplar kullanılabilirlik parametrelerine göre yapılan değerlendirme sonuçlarını destekler niteliktedir. Aktivite çeşitliliği sorusuna verilen cevaplar meydan kullanıcılarının farklılıklarını yansıtmakta, Vilayet Meydanı kullanıcılarının ağırlıklı olarak genç olması aktivite çeşitliliği talebini de arttırmakta ve aktivitelerin yeterliliğinin "kötü” olarak nitelendiği görülmektedir. Bununla beraber her iki meydanın hem gündüz hem gece kullanımının iyi olarak değerlendirilmesi meydanlara olan taleple birlikte, meydanlarda "güvenlik" hissinin olduğunu da göstermektedir.

Anket verilerinden kullanıcı talepleri sonuçlarına bakıldığında, kültürel açıdan önemli bir konumda yer alan tarihi Yayla Meydanı kullanıcıları bu bölgede yöresel ürünlerin yemeklerin satıldı̆̆ı noktalar talep ederken, Vilayet Meydanında aktivite çeşitliliğinin arttırılması talep edilmiştir. Önemli bir ayrıntı olarak kullanılabilirlik durumu ile ilgili yapılan değerlendirmede Vilayet meydan ve çevresinde aktiviteler yeterli görüldüğü halde meydan kullanıcıları için daha çok aktivite ihtiyacının olması, yine Yayla Meydanı için yerel iş sahipliğinin olması kullanılabilirlik durumu değerlendirmelerinde olumlu kabul edilmişken, kullanıcıların daha çok yerel iş olanağı talep etmeleridir. $\mathrm{Bu}$ kullanılabilirlik değerlendirmelerinde kullanıcı taleplerinin önemini göstermektedir. 


\section{SONUC VE ÖNERILER}

Araştırmada Kırklareli merkez ilçesi Yayla ve Vilayet meydanların kullanılabilirliklerini, kullanım nedenlerini, kullanıcı ihtiyaçlarını ne ölçüde karşıladıkları analiz ederek bu meydanlarda kullanılabilirliğin arttırılmasına ilişkin öneriler getirmek amaçlanmıştır. Bu doğrultuda öncelikle iki meydan kullanılabilirlik ana kriterlerine ilişkin alt başlıklara göre mekânsal analiz, gözlem ve sayım yapılarak incelenmiş, her iki meydan da yapılan kullanıcı anketleri ile kullanım durumu, memnuniyet ve talepler üzerinden çıkarımlar yapılarak meydan kullanılabilirliğine ilişkin farkındalık tartışılmıştır.

Meydan Kullanılabilirlik parametrelerine göre Yayla Meydanı kullanılabilirliğinin Vilayet Meydanı kullanılabilirliğinden daha uygun olduğu görülmüsstür. 27 değerlendirme parametresinden Yayla Meydanı için 21 parametre olumlu, Vilayet Meydanı için 14 parametre olumlu değerlendirilmiștir. Bu tespitlerle iki meydanın kullanılabilirliğinin arttırılmasına ilişkin hususlar ortaya çıkmıştır.

Kullanıcıların her iki meydan için istediği talepler meydan kullanılabilirliğinin arttırılmasına yönelik ihtiyaçları kullanıcı gözü ile değerlendirmektedir. Kullanıcıların meydanların etkin kullanılabilirliğine ilişkin yeterlilik/yetersizlikleri ortaya çıkartan anket çalışması ile etkin kullanım kriterlerinin değerlendirilmesinde belirlenen ölçütlere göre kullanılabilirlik değerleri arasında kullanıcı farkındalığı açısından bir ilişki vardır. Çıkan sonuçlara göre kullanıcıların birçok noktada farkındalıkları olduğu ve taleplerinin de bu yönde olduğu, ancak bazı noktalarda özellikle çevre kalitesine yönelik değerlendirmelerin öncelikli olmadığı görülmüştür. Bu sonuç kamusal alan kullanımlarında her yer'e ilişkin kullanıcı karakteristik özelliklerinin, alışkanlıklar, kültürel özellikler, eğitim ve yaşam şeklinin de talep ve tercihleri yönlendirdiği, tasarımsal yaklaşımlarda bu özelliklerin çok daha detaylı olarak araştırılmasının gerekliliğini göstermektedir.

Meydan kullanılabilirliğine ilişkin sonuçlar ve kullanıcı anket sonuçları dört anahtar parametre üzerinden değerlendirildiğinde;

- Erişilebilirlik için: her iki meydanda da kullanılabilirlik oranlarının arttırılmasında alt yapı sorunlarının giderilmesi, özellikle engelliler için düzenlemelerin yapılması, otopark alanlarının arttırılması, Vilayet Meydanında gerekli mekânsal düzenlemelerin yapılması, alanda bölünmüşlük ve parçalanmışlık hissi yaratan araç trafiğinin de bu kapsamda tekrardan düzenlenmesi gereklidir. Yaya yollarının yeniden analiz edilerek yaya yolu sürekliliğinin sağlanmasında gerekli düzenlemelerin yapılması, meydanı oluşturan kamusal mekânların bütünlüğünün sağlanarak araç yoğunluğuna uygun çözümler getirilmesi önerilmektedir.

- Sosyalleşme için: Her iki meydanı tercih eden kullanıcı sayısını arttırabilmek için mevcut oturma alanlarının arttırılması, meydan kullanım neden ve özelliklerine göre farklı etkinlikler düzenlenerek katılım ve çekiciliğin arttırılması önerilmektedir.

- Kullanım ve Aktivite Olanakları için: Yayla Meydanında yerel iş sahipliliğinin arttırılmasına izin veren yasal düzenlemeler ve gerekli alan ihtiyacının karşılanarak bu doğrultuda gerekli düzenlemelerin yapılması her yaştan kullanıcının ilgisi düşünülerek aktivite ortamlarının planlanması, her iki meydanda da aktivite çeşitliliğinin arttırılmasına ilişkin düzenlemelerin yapılması önerilmektedir.

- Konfor ve İmaj için: Vilayet Meydanında gözlenen kötü koku ve görüntüye neden olan etmenlerin ortadan kaldırılması, gürültüyü azaltabilecek peyzaj öğelerinin arttırılması, çevresel kalitenin arttırılması için gerekli kontrol ve temizlik çalışmalarının sürekliliğinin sağlanması önerilmektedir. Ayrıca yine Vilayet Meydanında görsel bütünlüğün sağlanmasında tasarımsal yaklaşımlarla bina cepheleri ve peyzaj düzenlemelerinin yapılması, her iki meydan için kullanıcı çeşitliliğine göre alternatif mekânlar düzenlenmesi önerilmektedir.

Araştırma, sonuçları itibarı ile meydan kullanılabilirliği değerlendirme ölçütlerinin belirlenmesinde kullanıcı özelliklerinin önemini ortaya çıkarmakta, yerel yönetimlerin planlama ve kentsel tasarım çalışmalarında Kırklareli Merkez kent meydanlarının düzenlenmesinde yararlanılabilecek, kullanıcı özellikleri detayında sosyolojik araştırmalarla zenginleştirilerek güncellenebilecek veri niteliği taşımaktadır. 


\section{Etik Standart ile Uyumluluk}

Çıkar Çatışması: Yazarlar herhangi bir çıkar çatışmasının olmadığını beyan eder.

Etik Kurul İzni: Bu çalışma için etik kurul iznine gerek yoktur.

\section{KAYNAKÇA:}

[1] GIRITTLİĞLU, C., (1991). Şehirsel Mekan Ögeleri ve Tasarımı, İ.T.Ü. Mimarlık Fakültesi Baskı Atölyesi, İstanbul., 48-49.

[2] KORÇA, P., TANTAN, B.,1997. CELA Building Toward Diversity, Council of Educators in Lanscape Architecture Annual Conference, Asheville, North Carolina.

[3] CARMONA, M., TIESDELL,S., HEATH,T., and OC,T., (2010), "Public Places Public Spaces: The Dimensions Of Urban Design”, Archtectural Press, UK., 137-209.

[4] MONGOMERY, J., (1998), “Making a city: Urbanity, Vitality and Urban Design”, Journal of Urban Design, 3, 93 116.

[5] URBAN TASK FORCE REPORT (1999), “Towards and urban renaissance”, Urban Task Force, London.

[6] THOMPSON, C., (2002), "Urban open space in the 21st century", Journal of Landscape and Urban Planning, 60 (2), 59-72.

[7] SHIRVANI, H.,1985. The Urban Design Process, Van Nostrand Reinhold Company, N.Y.

[8] KRIER, R., 1979. Urban Space, Academy Editions, London.

[9] ZUCKER, P., 1959. Town and Square From Agora to the Village Green, Columbia University Pres, New York.

[10] ÖNDER, S., AKLANOĞLU, F., 2002. Kentsel Açık Mekan Olarak Meydanların İrdelenmesi. S.Ü. Ziraat Fak. Dergisi No: 16(29) Konya 96-106.

[11] LYNCH, K., 1960. The Image of the City, The MIT Pres, Cambridge. MOUGHTIN, C., 1992. Urban Design "Street and Square". Butterworth Architecture, Oxford.

[12] ARKIN H., COLTON R.R., 1949. An Outline of Statistical Methods: Fourth Edition Paperback - January 1, 1949

[13] EYÜBOĞLU, A.,. VATANSEVER, N., 2007. Kırklareli Kentsel Sit Alanı Yerleşimi, Koruma Sorunları Ve Öneriler 3rd International Sympsium On Architect Sinan - Housing 12th - 13th Aprll 2007 Edirne

[14] GÜNDOĞDU, M., KURU, A., ÖZKÖK, M.K., (2016). "Kırklareli Kent Algısı Üzerine Deneysel Bir Çalışma", İdealkent Kent Araştırmaları Dergisi, Sayı 18 Ocak 2016 Sf: $48-79$ ISSN 1307-9905.

[15] NEUFERT, 2000. Neufert Yap1 Tasarım1 35.Bask1 BETA 2000, İstanbul.

[16] URL 1: https://www.pps.org Erişim tarihi: 16.05.2019

[17] URL 2: https://www.pps.org/article/grplacefeat Erişim Tarihi: 16.05.2019

[18] URL 3: https://www.youtube.com/watch?v=DS16DuLX-tc Erişim tarihi: 10.04.2018

[19] URL 4: http://www.kirklareli.net/eski-kirklareli-fotograflari/ Erişim tarihi: 10.04.2018

YAZAR NOTU: Kaynak gösterilmeyen tüm şekil, grafik ve tablolar orijinal olup, bu makale için yazarlar tarafindan hazırlanmıştır. 